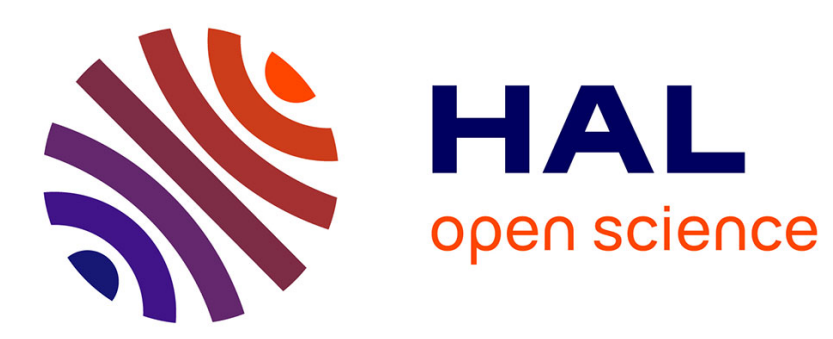

\title{
Collective exodigestion favours blow fly colonization and development on fresh carcasses
}

\author{
Quentin Scanvion, Valéry Hédouin, Damien Charabidzé
}

\section{To cite this version:}

Quentin Scanvion, Valéry Hédouin, Damien Charabidzé. Collective exodigestion favours blow fly colonization and development on fresh carcasses. Animal Behaviour, 2018, 141, pp.221 - 232. 10.1016/j.anbehav.2018.05.012 . hal-01839971

\section{HAL Id: hal-01839971 https://hal.science/hal-01839971}

Submitted on 16 Jul 2018

HAL is a multi-disciplinary open access archive for the deposit and dissemination of scientific research documents, whether they are published or not. The documents may come from teaching and research institutions in France or abroad, or from public or private research centers.
L'archive ouverte pluridisciplinaire HAL, est destinée au dépôt et à la diffusion de documents scientifiques de niveau recherche, publiés ou non, émanant des établissements d'enseignement et de recherche français ou étrangers, des laboratoires publics ou privés. 


\section{Collective exodigestion favours blowfly colonisation}

\section{and development on fresh carcasses}

3

4

5 Authors

6 Quentin SCANVION, Valéry HEDOUIN, Damien CHARABIDZE*

7

8 Author affiliations

9 CHU Lille, EA 7367 - UTML - Unite de Taphonomie Medico-Legale, Univ Lille, Lille, 10 France

12 Corresponding author: Damien CHARABIDZE, damien.charabidze@univ13 lille2.fr, Institut de Médecine Légale, rue André Verhaeghe, F-59000 Lille,

14 France, +33320623513

16 Article type: Original research article

Running head

19 Social strategies in necrophagous blow flies

20

21 Funding

22 We received no funding for this study.

24 Competing interests

25 We have no competing interests. 


\section{Abstract}

27 Necrophagous flies breeding on carcasses face high selection pressures and therefore

28 provide interesting opportunities to study social adaptations. We postulated that blowfly 47 necrophagous larvae gregariousness is an adaptive response to the environmental constraints of fresh carcasses. Cooperation is indeed believed to be a key to the global success of social species. To test this idea, the development of Lucilia sericata (Diptera: Calliphoridae) larvae growing on low- or high-digestibility food substrate (control or trypsin-added ground beef muscle, respectively) at different larval densities was monitored. Results showed that larvae developed faster and had decreased mortality at high larval density compared with low larval density. Furthermore, aggregation had no deleterious effect on the morphological characteristics (e.g., size) of post-feeding larvae and flies. We concluded that increased density positively affected population fitness, which is a conclusion consistent with the predictions of the Allee effect. Compared with regular food, larvae fed on high-digestibility food had reduced mortality and faster development on average. According to these results, we postulated that collective exodigestion might be an adaptive response allowing blowflies to colonise fresh carcasses before the arrival of other insects and the multiplication of microbes. This hypothesis is consistent with the idea that cooperation may enable species to expand their niches.

Keywords: Adaptive ecology, Aggregation, Allee effect, exodigestion, niche selection 
Collective behaviour is powerful adaptive strategy to cope with a harsh environment, and cooperation is believed to be a key to the global success of social species (Cornwallis et al., 2017). Although eusocial Hymenoptera such as bees and ants are well-known insect societies, gregarious insects also provide interesting examples of efficient collective strategies (Choe \& Crespi, 1997; Costa, 2006). Grassé, (1946) defined a part of social behaviour as a Mass effect, i.e., a group effect caused by a modification of the medium by the population itself. A striking example of this idea is provided by terrestrial crustacean woodlice, for which desiccation is a primary concern: in response to this environmental stress, aggregation offers group protection against drying (Broly et al., 2014). Deneubourg et al. (1990) also observed that bark beetle larvae aggregate and use communal feeding as a way to overwhelm the reaction of the tree. Similarly, social spiders collectively inject digesting enzymes and then suck up the liquidised prey content, thereby exploiting a common resource that was jointly created (Schneider \& Bilde, 2008). In flies, egg aggregations allow larvae to warm and moisten the organic material (Barnard \& Geden, 1993; Bryant, 1977), improve larval ability to dig and burrow into the food (Durisko et al., 2014), and limit the growth of competitive fungi (Rohlfs et al., 2005; Zvereva, 1986).

66

Blowflies (Diptera: Calliphoridae) are the most widespread and abundant necrophagous species and are attracted quickly after death (Smith, 1986). Female flies lay eggs on fresh vertebrates carcasses on which their larvae feed until metamorphosis; larvae are confined to the carrion until reaching a sufficient mass/instar. Although some studies report competition among carrion flies larvae (Denno \& Cothran, 1975, 1976; Feinberg \& Pimentel, 1966; Hanski, 1987; Ives, 1991),

73 Flores et al. (2017) observed that female flies do not preferentially oviposit on carcasses without larvae, and several studies show that ovipositing gravid blowflies 
enhance the attractiveness of a carrion (Brodie et al., 2014; Denno \& Cothran, 1975; Jiang et al., 2002; Kneidel, 1984; Wertheim, 2005). Therefore, egg aggregation is clearly not avoided and is even sought by adult blow flies. Furthermore, during the three feeding instars, calliphorid larvae actively aggregate (Boulay et al., 2013, 2016): masses of several thousands of larvae are commonly observed in the field (Fenton et al., 1991; Slone \& Gruner, 2007). Because females and larvae should avoid competition, whether necrophagous larval aggregation is advantageous is a reasonable question (see Table 1). When they reach a sufficient weight, late thirdinstar disperse to find sheltered places for pupation, a process known as postfeeding larval dispersal (Gomes et al., 2006). Consequently, postfeeding larvae and pupae are not subject to the same selection pressure than feeding instars.

Table 1: The benefits and costs of gregariousness necrophagous larvae of calliphorids flies.

\begin{tabular}{|l|l|}
\cline { 2 - 3 } \multicolumn{1}{c|}{} & \multicolumn{1}{|c|}{ BENEFITS } \\
\hline Temperature & $\begin{array}{l}\text { The mechanisms remain hypothetical When the temperature approaches the } \\
\text { (larval metabolism, permanent friction thermal tolerance range of the larvae, self- } \\
\text { of larvae, microbial activity), but heat regulation processes within the mass must } \\
\text { production by large larval masses is be initiated, which reduce the time allocated } \\
\text { clearly demonstrated (Charabidze et to feeding and therefore the growth rate } \\
\text { al., 2011; Gruner et al., 2017; Heaton et (Charabidze, Hedouin, \& Gosset, 2013). } \\
\text { al., 2014; Slone \& Gruner, 2007). The } \\
\text { microclimate inside the mass should } \\
\text { increase the developmental speed of } \\
\text { maggots. } \\
\text { Food } \\
\text { availability }\end{array}$ \\
$\begin{array}{l}\text { Cooperative exodigestion was After a critical number of individuals are } \\
\text { supposed but not experimentally reached, the availability of nutrients per }\end{array}$ \\
\hline
\end{tabular}




\begin{tabular}{|c|c|c|}
\hline & demonstrated (Rivers et al., 2011). & $\begin{array}{l}\text { individual becomes insufficient, leading to } \\
\text { decreases in the speed of development, } \\
\text { survival, and weights and sizes (Table A1). }\end{array}$ \\
\hline $\begin{array}{l}\text { Physico- } \\
\text { chemical } \\
\text { modifications }\end{array}$ & $\begin{array}{l}\text { Increasing the mass may protect larvae } \\
\text { against evaporation and temperature } \\
\text { decreases (Broly et al., 2014; } \\
\text { Huntington et al., 2007; Pérez et al., } \\
2016 \text { ). }\end{array}$ & $\begin{array}{l}\text { Excreta rich in ammonia accumulates } \\
\text { (Hobson, 1931). }\end{array}$ \\
\hline $\begin{array}{l}\text { Predators } \\
\text { and parasites }\end{array}$ & $\begin{array}{l}\text { High population densities can reduce } \\
\text { the risk of predation/parasitism but } \\
\text { remains to be demonstrated for } \\
\text { necrophagous species (Hunter, 2000; } \\
\text { Rohlfs \& Hoffmeister, 2004). }\end{array}$ & $\begin{array}{l}\text { Chemical signals of the larvae and } \\
\text { metabolites increase as a result of feeding } \\
\text { (no experimental evidence, see (Frederickx } \\
\text { et al., 2014). }\end{array}$ \\
\hline Other & $\begin{array}{l}\text { Repulsion of scavengers and burying } \\
\text { beetles: female burying beetles typically } \\
\text { exploit carcasses without blowfly larvae } \\
\text { (smith, 1986). } \\
\text { Scavengers may avoid carcasses } \\
\text { heavily colonised by larvae and/or } \\
\text { bacteria (devault et al., 2004). }\end{array}$ & $\begin{array}{l}\text { Increased risk of disease: many pathogens } \\
\text { are transmitted in a density-dependent } \\
\text { fashion, but this phenomenon has not been } \\
\text { demonstrated in necrophagous larvae } \\
\text { (Pöppel et al., 2015). }\end{array}$ \\
\hline
\end{tabular}

Adapted from Rivers et al. (2011).

91 Necromass is by nature a discrete and ephemeral food source. Decomposition 92 processes quickly alter flesh (Clark et al., 1997), and the probability of carcass removal 93 by scavengers increase with time and decomposition odour (DeVault et al., 2004). As 94 pioneer species, blowflies strategy depends on their ability to quickly colonize carrions 
(Denno \& Cothran, 1975). Furthermore, many birds, wasps and necrophagous insects prey on maggots. Voss et al. (2009) report an overall $11.8 \%$ paratism of maggots, and Frederickx et al. (2013) observed that on average, $48 \%$ of fly pupae were killed by hymenopteran parasitoids (from 3.5\% in May to $90 \%$ in September). When the larvae develop rapidly, less time is spent on the cadaver and probability of a food shortage, predation, parasitism and interspecific competition decrease (DeVault et al., 2004; Rivers et al., 2012). That can noticeably be achieved by favouring high-temperatures that increase their development speed (Aubernon et al, 2016, Grassberger \& Reiter, 2001). In this respect, a well-known adaptive strategy of blow flies larvae is the socalled maggot-mass effect, a local temperature increase attributed to larval metabolism (Charabidze et al., 2011; Slone \& Gruner, 2007). Because additional heat gain reduces developmental time, aggregated larvae benefit from this larval-mass effect with faster development than that of isolated individuals (Erzinçlioglu, 1996; Heaton et al., 2014; Johnson \& Wallman, 2014). In the same way, aggregation can protect larvae from abrupt decreases in temperature (Huntington et al., 2007; Magni et al., 2016; Rivers et al., 2011). However, these thermal effects mostly occurs during late feeding instars and only within large masses above a thousand larvae (Charabidze et al., 2011; Heaton et al., 2014). Here, we postulated that beside maggot-mass effect, gregariousness favours necrophagous larvae feeding and their early exploitation of fresh carcasses.

According to Disney (1986), the switch to ingesting liquid instead of solid food could be a fundamental revolution in the evolution and diversification of flies. Necrophagous larvae are actually unable to ingest solid particles other than those that are microscopic, and their buccal apparatus is not suitable for mastication (Guyénot, 1907). Therefore, larvae must liquefy the food before ingestion (i.e., exodigestion). The necrophagous larvae of calliphorid flies excrete/secrete various proteolytic enzymes, including trypsin, lipases and amylases (Chambers et al., 2003; Hobson, 1931; Rivers 
122 et al., 2011; Terra \& Ferreira, 1994). The sharing of enzymes has been reported as a

123 likely benefit of calliphorid larval aggregation, but this idea has never been 124 demonstrated (Ireland \& Turner, 2006; Reis et al., 1999; Rivers et al., 2011). To test

125 the hypothesis of collective benefits through exodigestion, L. sericata larvae were bred 126 at different larval densities. Two hypotheses were experimentally tested: (1) larval 127 development speed and survival increases with increasing larval density, and (2) larval 128 development speed and survival increases with increasing food digestibility.

\section{MATERIALS AND METHODS}

\section{Ethical note}

132 This research adheres to the ASAB/ABS Guidelines for the Use of Animals in 133 Research, the legal requirements of the country in which the work was conducted, and 134 all institutional guidelines. During the design of the study, a minimum of manipulation 135 with a minimum of used animals was sought.

\section{Insect rearing}

138 Lucilia sericata larvae were obtained from adult flies bred in the laboratory and 139 maintained in tulle cages $(50 \times 50 \times 50 \mathrm{~cm})$ at room temperature $\left(23 \pm 2^{\circ} \mathrm{C}\right)$. Wild flies, 100 140 to 200, were added every 2 months. The flies were fed caster sugar and water ad 141 libitum. After each new generation, minced beef liver was added for 7 days to provide 142 proteins for vitellogenesis and then removed. Laying of eggs was triggered with the 143 placement of $25 \pm 5 \mathrm{~g}$ of beef liver for $2 \mathrm{~h}$ (from 10 a.m. to midday) in cages. Oviposition 144 time (precision $\pm 1 \mathrm{~h}$ ) was noted as $\mathrm{D}-1$ (see Fig. 1). 


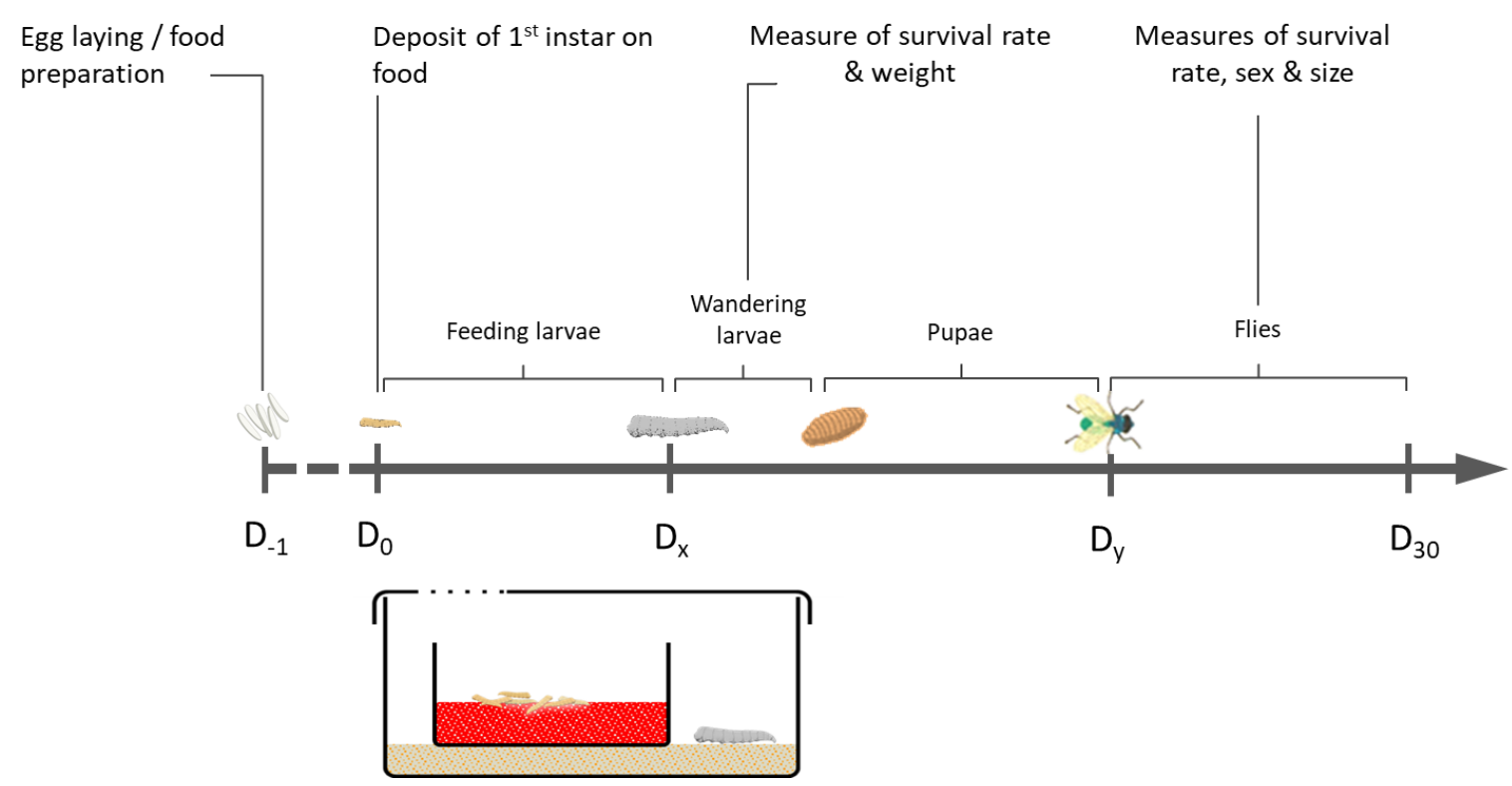

Figure 1: Chronological diagram of the experimental process. $D_{-1}$ is the time of oviposition $( \pm 1 \mathrm{~h})$. Larvae were counted and placed on food on the next day $\left(D_{0}\right) . D_{x}$ is the first post-feeding larva and $D_{y}$ is the first emerging fly.

\section{Larval development}

A density-dependent increase in competition is found in many blowfly developmental studies (see Table A1). In some studies, measurements were conducted during the feeding of instars, which likely disrupts aggregates and prevents detection of any social benefit (Martinez Sanchez et al., 2007; Simkiss et al., 1993). Many others suffer from a lack of statistical power (few replications, time between measures too long) (Martinez Sanchez et al., 2007; Reigada \& Godoy, 2006; Saunders \& Bee, 1995; Serra et al., 2011). Finally, many authors used mixed liver or synthetic medium to feed larvae (Martinez Sanchez et al., 2007; Reis et al., 1999; Simkiss et al., 1993; Smith \& Wall, 1997). These food sources are more digestible and less nutritious than muscular tissues and significantly affect larval development (Barnes \& Gennard, 2013; Bernhardt et al., 2017; El-Moaty \& Kheirallah, 2013; Pérez et al., 2016, 2016; Rueda et al., 2010; Tachibana \& Numata, 2001). By contrast, our experiments were performed with relevant larval densities feeding on beef muscle, a realistic food source. 
166 All experiments on development were conducted from January to May 2017 in a

167 thermostatic chamber set at $25 \pm 0.1^{\circ} \mathrm{C}$ with constant ventilation (ST4; POL-EKO 168 Aparatura $®$, Wodzisław Śląski, Poland). A 12:12 h photoperiod cycle was obtained with 169 a fluorescent tube placed inside the incubator (430 lumens, light from 9:30 a.m. to 9:30 170 p.m.).

171

172 Eggs obtained at Day -1 were incubated for $22 \mathrm{~h}$, and then first instars were counted 173 and placed in boxes containing food (D0). Each box was placed in a second box 174 containing $1 \mathrm{~cm}$ of sand. All experiments were performed at $25^{\circ} \mathrm{C}$. Two independent 175 variables were studied: the initial number of larvae (i.e., larval density) and the 176 digestibility of the food. Six replications for densities d10, d50, d100, and d250 and 177 three replications for density d500 were prepared for each food type.

178

179 Two independent variables were studied: the initial larval population (i.e., larval density) 180 and the digestibility of the food. The larval densities (d) tested were 10, 50, 100, 250 181 and 500 larvae per $50 \pm 1 \mathrm{~g}$ of food, low enough to prevent maggot-mass effect (i.e significant local temperature increase, Charabidze et al., 2011). Two types of food were used: the control food $(\mathrm{C})$ was $50 \pm 1 \mathrm{~g}$ of minced beef muscle at $15 \%$ fat mixed with 15 $\mathrm{mL}$ of $0.9 \% \mathrm{NaCl}$, and pre-digested food $(\mathrm{Tr})$ was obtained with the same meat mixed with $50 \pm 0.5 \mathrm{mg}$ of trypsin (Trypsin T4799, porcine pancreas; Sigma-Aldrich®) diluted in $15 \mathrm{~mL}$ of $0.9 \% \mathrm{NaCl}$. The addition of trypsin changes food digestibility (the size of the molecules) but not the composition or nutritional value of the meat. The beef muscle was thawed for $6 \mathrm{~h}$ at ambient temperature, mixed according to the twoabovementioned modalities and placed in translucent polypropylene boxes (100x75x63 $\mathrm{mm}$ ). Six replications for densities d10, d50, d100, and d250 and three replications for density d500 were prepared for each food type. 


\section{Experimental procedure}

194 The eggs obtained at D-1 were incubated at $25^{\circ} \mathrm{C}$ for $22 \mathrm{~h}$ (first instar; see Fig. 1) 195 (Grassberger \& Reiter, 2001). The next day (D0), young first instars were counted and 196 placed in the boxes containing food. Each box was placed in a second translucent 197 polypropylene box $(180 \times 135 \times 195 \mathrm{~mm})$ containing $1 \mathrm{~cm}$ of sand. To preserve 198 aggregation and avoid disturbance of feeding larvae, no measurements were 199 performed on feeding instars. Only wandering larvae (also called post-feeding larvae, 200 i.e., third instar larvae that had finished feeding and left the food) were measured. The 201 post-feeding larvae and adult flies were checked three times a day (10:00 a.m., 4:00 202 p.m., 10:00 p.m.).

Post-feeding larvae found in the sand were quickly rinsed with water and dried on absorbent paper. After weighing (Kern® ALT310-4, Grass Valley, USA), these postfeeding larvae were placed in new boxes $(100 \times 75 \times 63 \mathrm{~mm})$ containing $1 \mathrm{~cm}$ of sand. The few larvae that left the food before the third instar or weighed less than $25 \mathrm{mg}$

207 (below the first percentile) were not counted as post-feeding larvae. The mortality rate 208 to post-feeding and the weighted mean of larval weights per replication were 209 calculated.

210 Newly emerged flies were sampled, left in development for at least $6 \mathrm{~h}$, and then sacrificed by freezing. The flies were sorted by sex using cephalic morphology

212 (Erzinçlioglu, 1996). The area of the right wing was measured to estimate the sizes of 213 males and females (Saunders \& Bee, 1995). Data were recorded by taking pictures of 214 dissected and flattened right wings, with the surface area determined using ImageJ software (version 1.51j8, Wayne Rasband, National Institutes of Health, USA, public domain). All female and male flies from densities 10 and 50 were analysed. Random samples of 25 male flies and 25 female flies per replication were analysed for the

218 densities 100, 250 and 500. 
221 Statistical tests were conducted bilaterally, with a significance threshold of $\alpha=0.05$.

222 When appropriate, 95\% bilateral confidence intervals are presented. All data were 223 analysed with $R$ software via $R$ studio ( $R$ version 3.3.2@2016; The $R$ foundation for

224 Statistical Computing | Version 1.0.136@2009-2016 RStudio Inc.).

225 A logistic regression model (quasibinomial with a link function cauchit) was used for the 226 statistical analysis of larval development times. The variables to explain were (i) the 227 proportion of post-feeding larvae and (ii) the flies present during the respective periods 228 from D2 to D5 and D11 to D15. A step-by-step selection technique was used to 229 improve the model. The AIC criterion (Akaike Information Criterion) was used to determine the quality of a model. For this reason, the model was applied to each food type separately, with time and larval density as explicative factors. Then, the model was applied to compare the effect of food at each density, with time and substrate the explicative factors. ANOVA was used to determine the significance of the model 234 factors.

235 The odds ratio (OR) of each explicative variable was calculated, which provides an estimate (with confidence interval) for the relationship between two binary variables: when the OR is greater than 1, the two variables are considered associated. Chi-square tests were used to compare mortality rates by food type, and when significance was detected, pairwise post hoc tests were applied.

240 Two-way ANOVAs (density, food) were used to compare morphometric parameters 241 (size and mass). The data for size of flies from the few individuals of the d10 larval 242 density were insufficient (or even absent for one sex); therefore, we excluded the d10 243 data from the ANOVAs: only descriptive results are presented.

\section{RESULTS}

\section{Effects of larval density}


247 The proportions of post-feeding larvae according to development time are shown in 248 Fig. 2(a) (control food condition). The logistic regression model showed a significant 249 effect of larval density on the proportion of post-feeding larvae $(P<0.001)$. The 250 development time decreased with larval density above 50 and up to 250 larvae and 251 then slightly increased at d500 (see Fig. 2(a) for odds ratio of each density condition 252 versus d10). The logistic regression model also demonstrated a significant effect of 253 larval density on the development time until emergence, but this effect was less 254 pronounced $(P<0.001$, see Fig. 3(a)).

255 Early larval mortality rates (from first instar to post-feeding) were significantly affected by larval density $\left(X^{2}=101.4, P<0.001\right)$. The pairwise post hoc test highlighted a decrease in mortality with the increase in larval density (see Fig. 4(a)). Considering overall mortality (from first instar to emergence), a significant decrease with increasing larval density was also observed $(P<0.001$; see Fig. 4(b)).
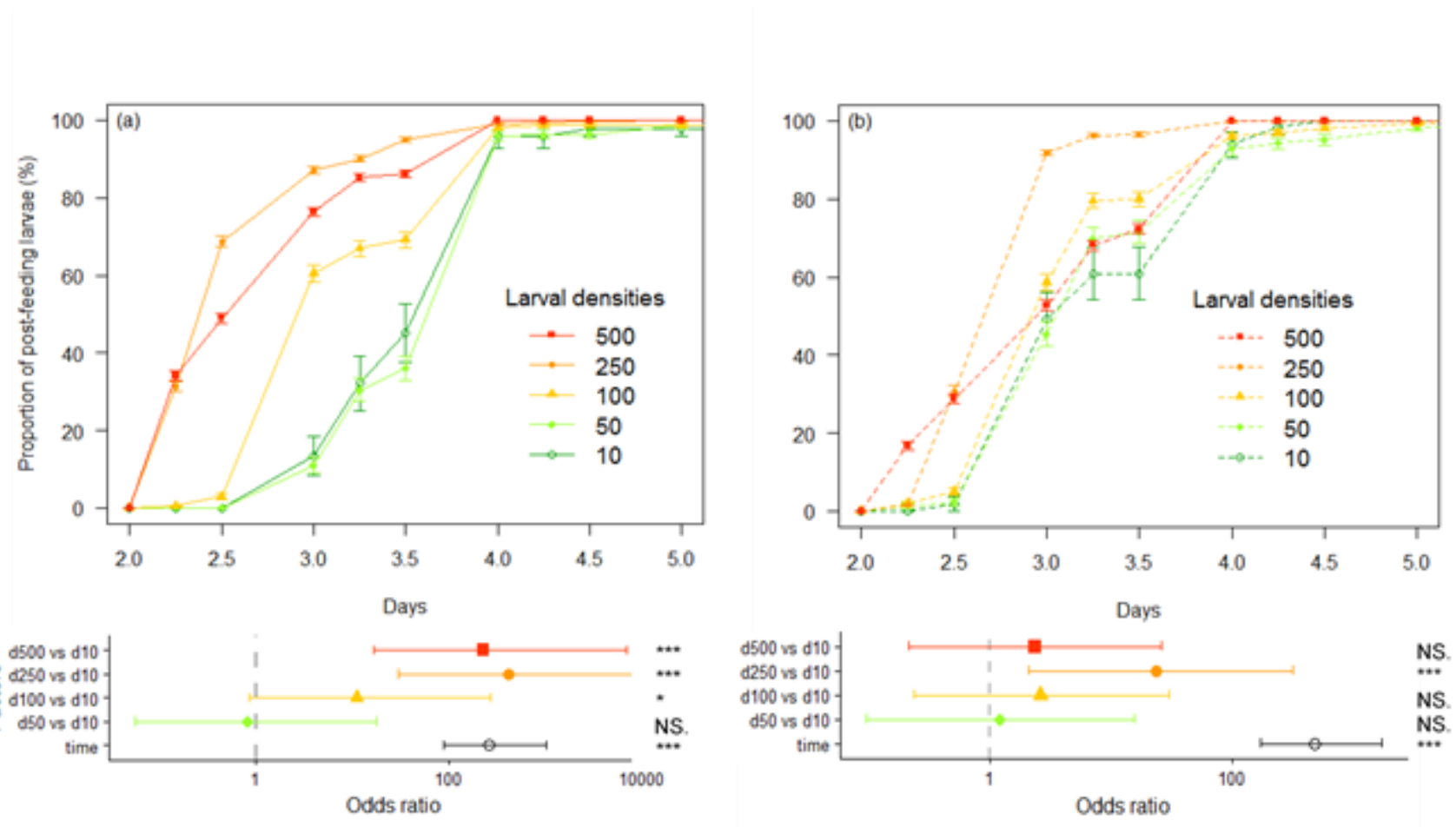

260 Figure 2: Kinetics of transition from larvae to post-feeding instars: (a). control food; (b). 261 food with addition of trypsin. Percentages \pm SE of post-feeding larvae are given in relation to larval densities. Odds ratios with $95 \%$ confidence interval of the logistic 
regressions are also given. $\mathrm{d}=$ no. of larvae $/ 50 \mathrm{~g}$ of food; $N S$. $=$ not significant; * $264 P<0.05,{ }^{* * *} P<0.001$.
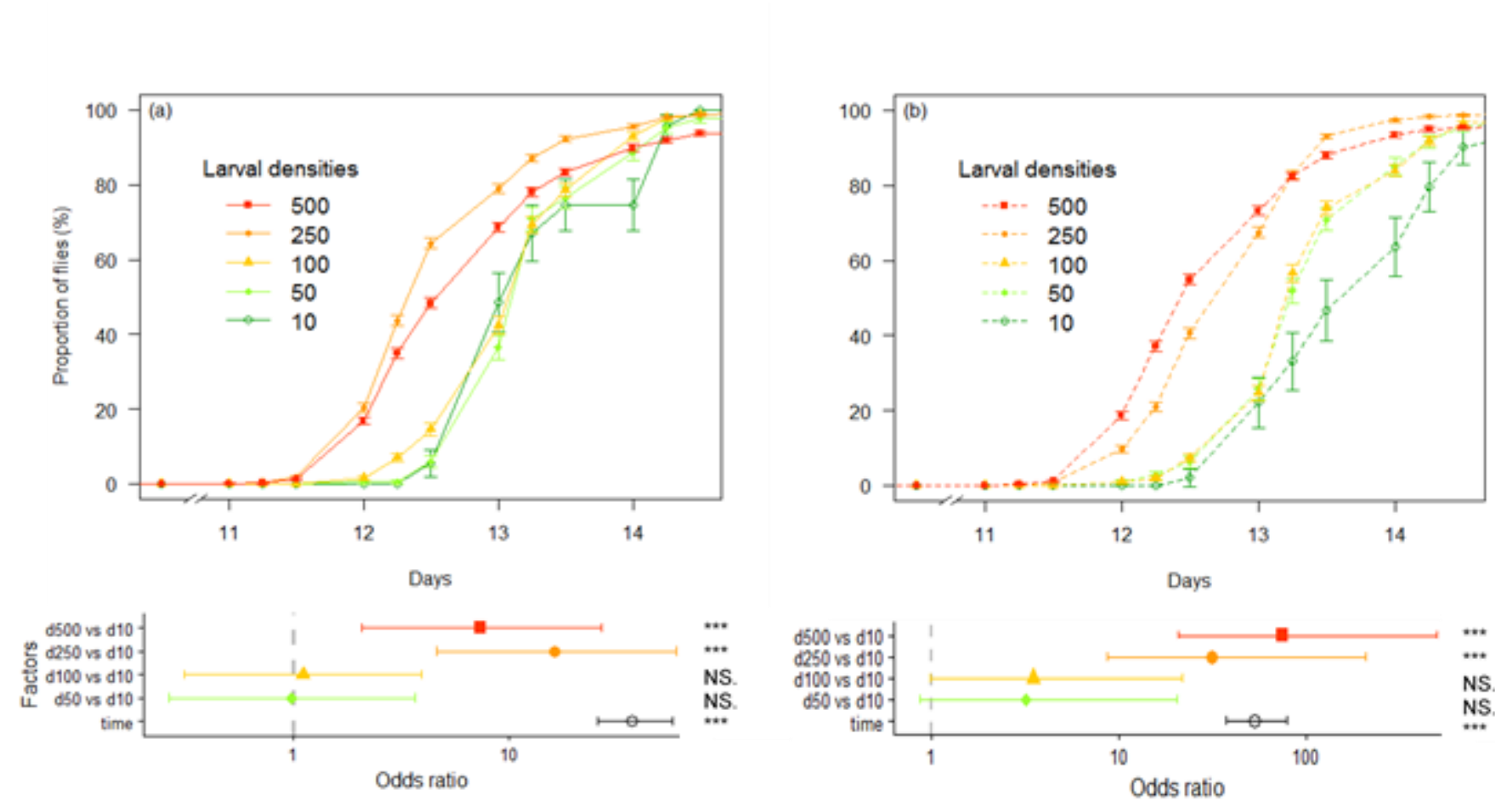

Figure 3: Kinetics of imago emergence: (a) control food; (b) food with addition of trypsin. Percentages $\pm \mathrm{SE}$ of imagos are given in relation to larval densities. Odds ratios with $95 \%$ confidence interval of the logistic regressions are also given. $d=$ no. of larvae $/ 50 \mathrm{~g}$ of food; $N S$. = not significant; ${ }^{* *} P<0.001$.
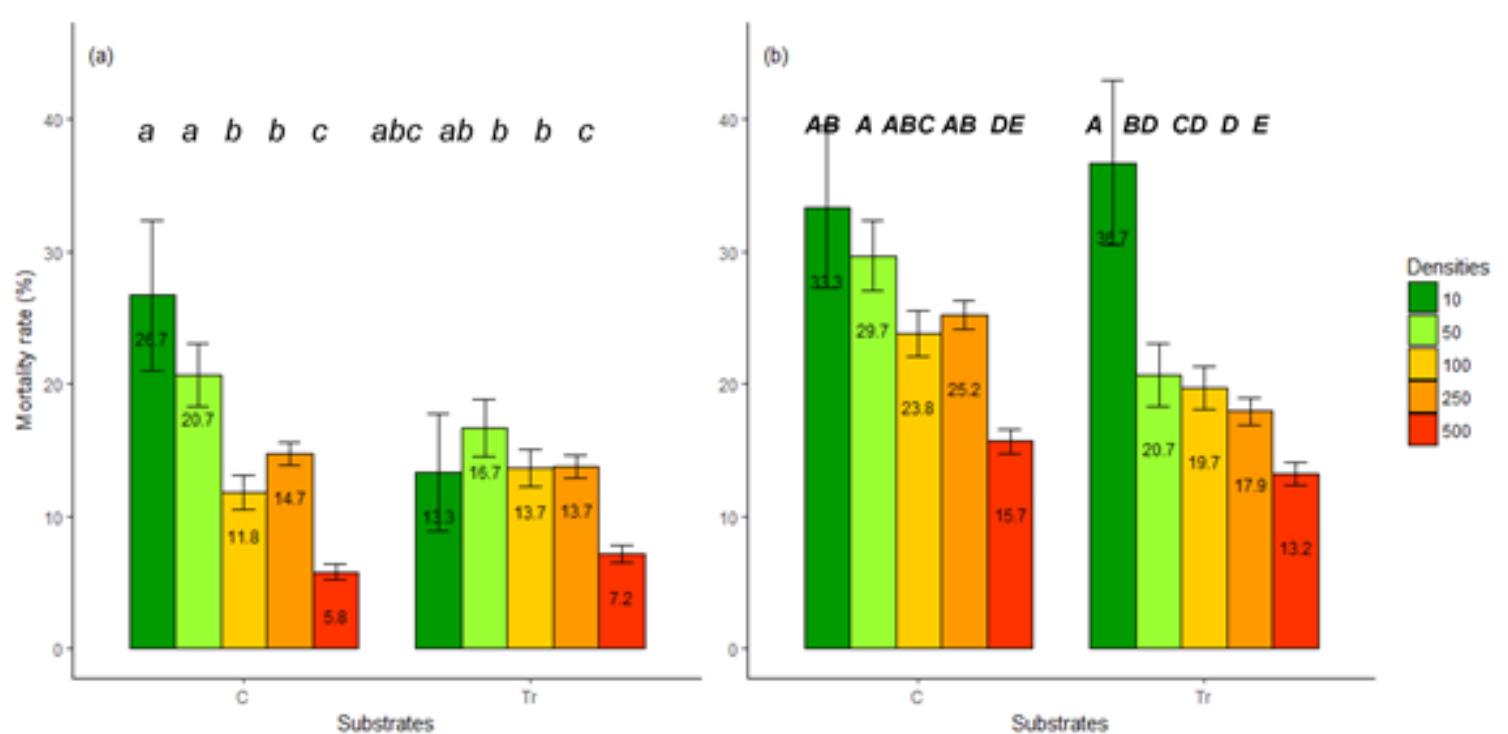

Figure 4: Average mortality rate (numbers in bars) \pm SE from first instar (a) to postfeeding and (b) to emergence. $\mathrm{C}=$ control food; $\mathrm{Tr}=$ trypsin-added food; densities = no. of larvae $/ 50 \mathrm{~g}$ food. Columns with the same letters are not significantly different ( $P>0.05)$. 
277 The addition of trypsin reduced larval development time at low densities, but did not 278 eliminated the benefits of gregariousness at highest densities $(P<0.001$; see Fig. 2(b)).

279 Compared with the control food, the average larval development time on trypsin-added 280 food was shorter at d10 and d50 $(P<0.001)$, was similar at d100 $(P=0.27)$ and was longer at d250 and d500 ( $P<0.001$ and $P=0.01$, respectively) (see Fig. 5). Development time was significantly reduced at d250 versus d10 (OR=23.4[2.1-309.8], $P<0.01)$; but with the other increases in larval number, larval development time did not significantly decrease. Regarding development time to fly emergence, a significant effect of density was observed at $\mathrm{d} 250$ and $\mathrm{d} 500(P<0.001, \mathrm{OR}=31.4$ [8.7-207.4] and 74.9 [20.7286 499.8], respectively; see Fig. 3(b) and Fig. A1). Larval mortality rates on trypsin-added food were also influenced by larval density $\left(X^{2}=45.5, P<0.001\right)$, with the mortality at $\mathrm{d} 500$ significantly lower than that at other densities $(P<0.001$, pairwise post hoc tests, see Fig. 4). No significant effect of trypsin on the total development time was detected, with the following $p$-values: $\mathrm{d} 10: P=0.08$; d50: $P=0.30 ; \mathrm{d} 100: P=0.91 ; \mathrm{d} 250: P=0.97 ;$ and d500, $P=0.17)$.

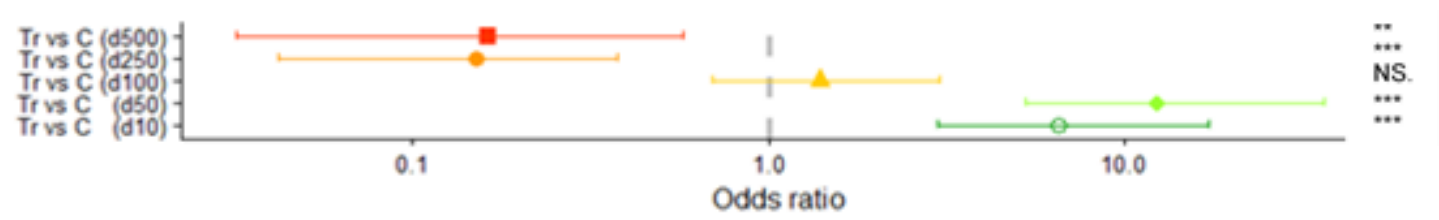

293

294

295

296

297

298

299

300

301

Figure 5: Odds ratios with 95\% confidence interval of the effect of trypsin-added food versus control food for larval development time (first instar to post-feeding). $d=$ no. of larvae $/ 50 \mathrm{~g}$ of food; $\mathrm{Tr}=$ trypsin-food; $\mathrm{C}=$ control food; $N S$. = not significant; ${ }^{* *}$ $P<0.01,{ }^{* * *} P<0.001$.

\section{Morphometrics}

The mean weight ( \pm standard error) of post-feeding larvae was $55 \pm 0.4 \mathrm{mg}$ (all conditions combined). Larval density $(F=1.41, P=0.24)$ or food type $(F=1.93, P=0.17)$ did not affect the weight (see Fig .A2). 
302 The male to female sex ratio was $0.99 \pm 0.003$ and was not modified by experimental 303 conditions $\left(X^{2}=5.84, P=0.76\right)$. Wing surface area of the flies (see Fig A3) was not 304 affected by larval density or by food type for either females $(F=1.81, P=0.14 ; F=0.40$, $305 P=0.53$, respectively) or males $(F=2.24, P=0.08 ; F=1.63, P=0.20$, respectively). The 306 mean right wing surface area was $15.7 \pm 0.1 \mathrm{~mm}^{2}$ for females and $13.1 \pm 0.1 \mathrm{~mm}^{2}$ for 307 males. As expected, males were smaller than females $(F=922.2, P<0.001)$.

\section{DISCUSSION}

310 Experiments demonstrated (1) a decrease in development time and mortality with

311 increasing larval density and (2) a decrease in development time and mortality on high-

312 digestible food compared with low-digestible food (at low densities of larvae). These 313 results provide evidence of the benefits of collective exodigestion and aggregation and possibly of much larger consequences at the community level such as niche 315 partitioning.

\section{Aggregation of necrophagous larvae is consistent with the Allee effect}

318 Increasing larval density resulted in better development of $L$. sericata larvae on the

319 control fresh meat. With the increase in larval density, (i) L. sericata development time 320 was reduced, and (ii) mortality decreased. Due to the selection pressure on the feeding 321 maggots (competition with scavengers, food shortage, parasitism and 322 interspecific/interkingdom competition), their survival notably depends on development 323 time (Benbow et al., 2015, DeVault et al., 2004; Frederickx et al., 2013, Hanski, 1987; 324 Jordan \& Tomberlin, 2017). Thus, the observed difference in developmental time with 325 density might have even more dramatic impact on larval survival in the field. 326 Furthermore, larval density did not affect adult fly morphometrics: larvae growing in the 327 large groups assimilated sufficient food fast enough not to affect their metamorphosis 
328 and final size/weight (Charabidze et al., 2013). As the fertility of a female depends on

329 its size (Saunders \& Bee, 1995), we reasonably concluded that increased density had 330 no deleterious effect and positively affected population fitness, which is a result 331 consistent with the predictions of the Allee effect (i.e., a positive relationship between 332 fitness and population size) (Allee, 1927; Courchamp et al., 2008).

333 Inside larval masses, two collective strategies likely act synergistically. Maggot-mass 334 effect, which is a local temperature increase inside large aggregates, was formerly 335 postulated as one of the primary benefits of larval pre-social behaviour (Rivers et al., $3362011,2012)$. However, significant local warming requires many more larvae than those 337 used for this study (see Fig. A4). As an example, a 24-h decrease in development time 338 as we observed with 250 larvae groups in the present work would require a local 339 temperature shift from $25^{\circ} \mathrm{C}$ to $34^{\circ} \mathrm{C}$ (Grassberger \& Reiter, 2001), which is warming 340 that is only reached above 5690 aggregated larvae (Charabidze et al., 2011). By

341 contrast, exodigestion occurs at the scale of a single egg-batch (circa 200 larvae) and 342 is fully efficient as soon as a few hundred larvae aggregate and feed together. This 343 initial benefit can be reinforced by the aggregation of additional larvae, resulting in 344 maggot masses sufficiently large to increase local temperature (see Fig. 6 and 7).

346 This aggregation strategy of necrophagous blowflies may rely on the genetic proximity 347 of feeding larvae, a result previously described in caterpillars (Tsubaki \& Shiotsu, 348 1982). Indeed, the genetic affinity within aggregated larvae is inherently close: each 349 female fly lays egg batches of circa 200 eggs, resulting in hundreds of aggregated 350 offspring (Wall, 1993). Picard \& Wells (2010) also found that gravid females ready to oviposit on the same carcass showed a pattern of relatively high relatedness. 


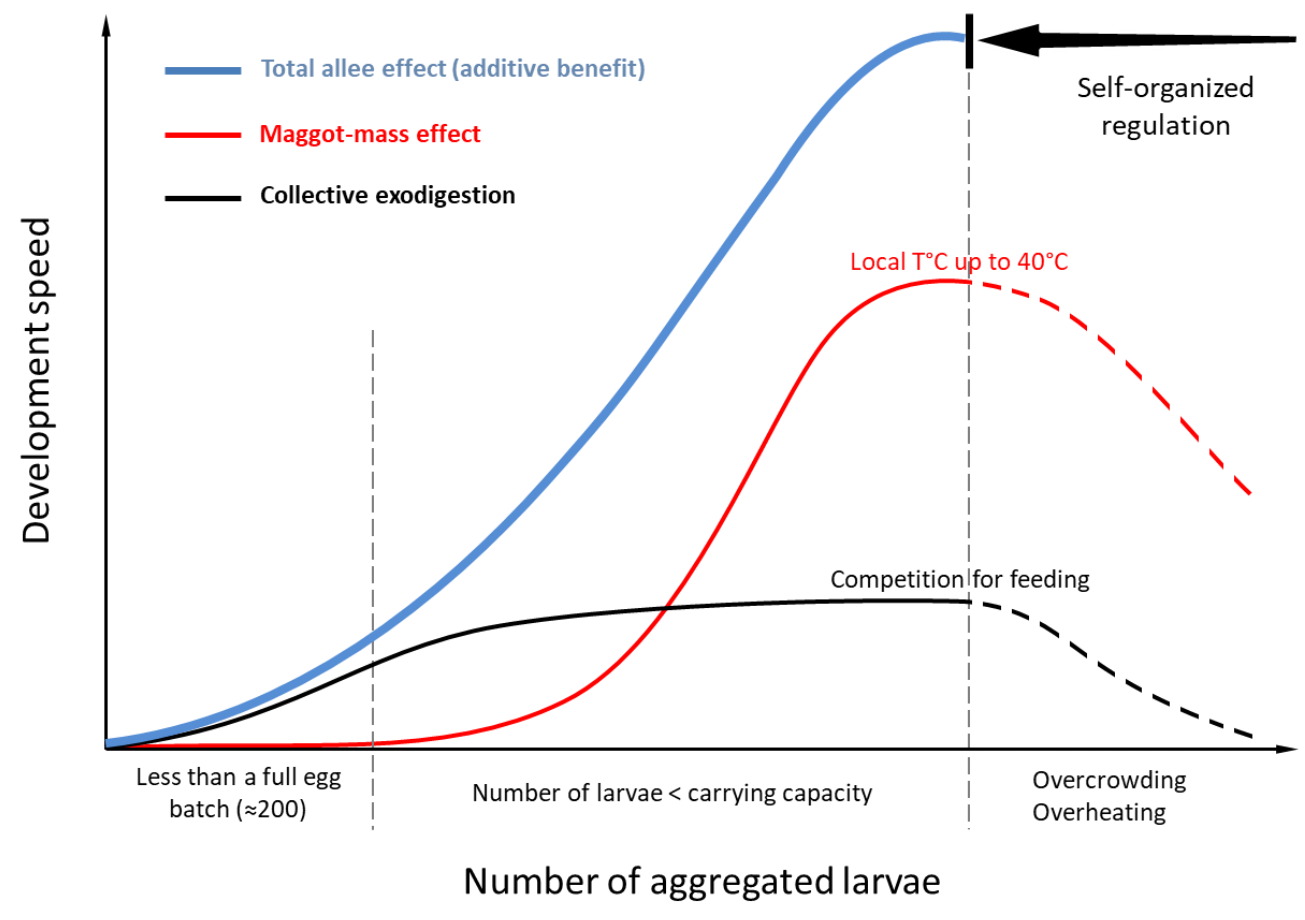

352

353

354

355

356

357

358

Figure 6: Schema of the benefit to development speed (i.e. gain) of increasing numbers of aggregated larvae. .

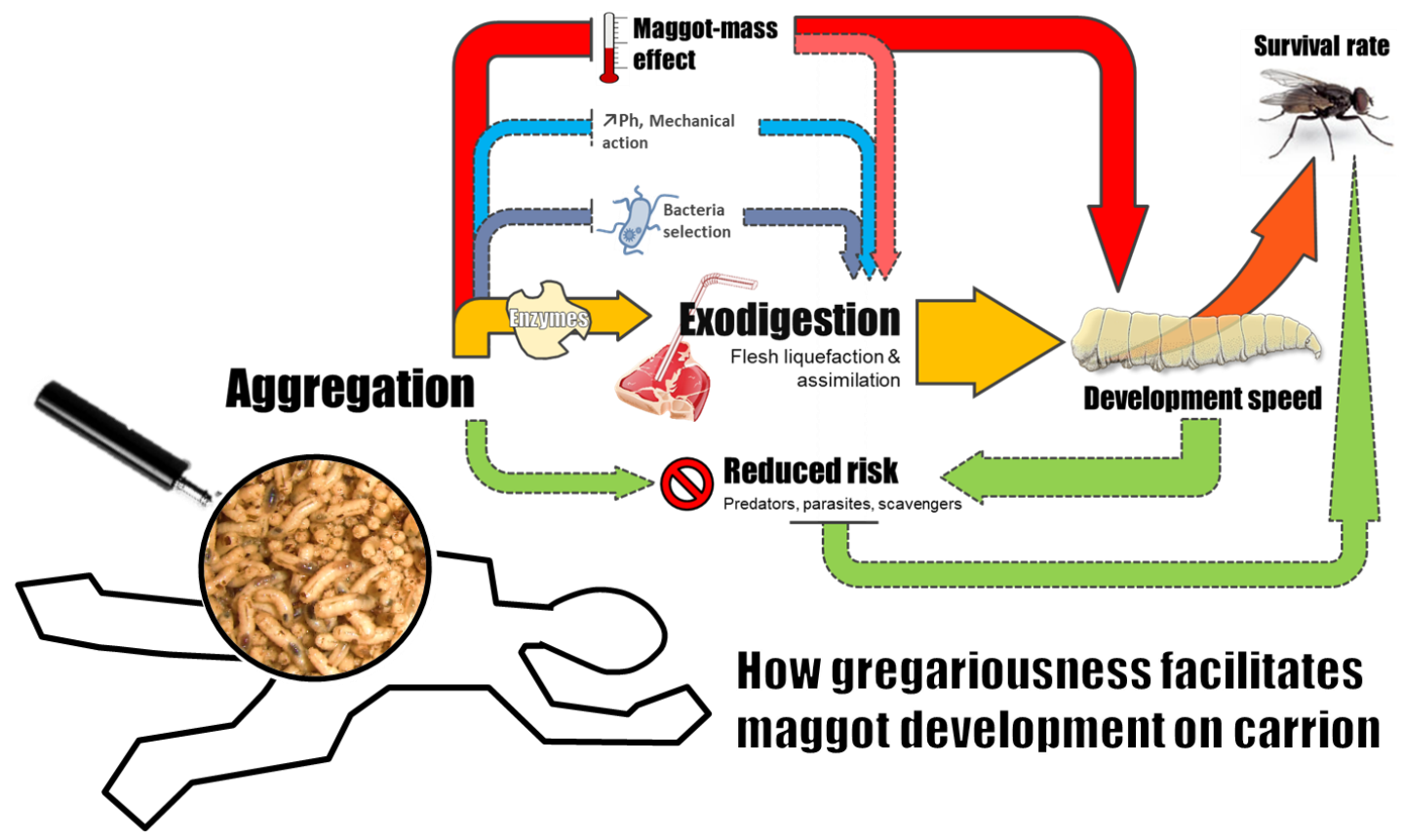

Figure 7: Summary of demonstrated (solid arrows) or hypothetical (dotted arrows) benefits of necrophagous larvae gregariousness. 


\section{Gregariousness may be a blowfly adaptive strategy to breed on fresh carcasses}

363 The results obtained with trypsin-added food also highlight the benefits of aggregation.

364 Compared with those fed fresh control food, larvae fed on high-digestibility food had reduced average mortality and slightly faster development. Therefore, we assumed that the increased development and reduced mortality of aggregated larvae resulted in part from chemical degradation (pooling of enzymes). Consistent with this idea, Wilson et al. (2016) demonstrated that the addition of a trypsin inhibitor drastically reduces exodigestion and slows $L$. sericata larval growth. Green et al. (2002) also showed that feeding activity of groups of Phormia regina larvae has a greater effect on the chemical nature of the diet surfaces than the feeding of isolated larvae. However, while trypsinadded food significantly decreased mortality rates at d10, this increased survival was offset by a higher mortality during post-feeding instars (see Fig. 4). This "catching up" effect resulted in a similar global (i.e. first instar to emergence) mortality on both food types. One likely hypothesis is that the addition of trypsin facilitates the ingestion and digestion of the food, and thus allows the weakest larvae (those whom died on control experiments) to survive artificially (Barnard \& Geden, 1993). However, many of these larvae were living on borrowed time and they died during post-feeding or pupal development. Furthermore, the addition of trypsin did not completely eliminate the benefits of gregariousness in terms of development time (electronic Table A1). Two cofactors of exodigestion might explain why trypsin does not fully imitate the properties of aggregated larvae. First, larval alkalisation of the medium can increase the $\mathrm{pH}$ dependent enzymatic degradation (Hobson, 1931). Second, a density-dependent selection of competing bacteria may be an important consequence of larval aggregation (Arce, Smiseth, \& Rozen, 2013). Indeed, Janzen's "spoiling theory" (Janzen, 1977) hypothesises that bacterial decomposers should produce compounds that cause rich and ephemeral resources to rot, rendering them unpalatable, whereas animals should evolve adaptive strategies of avoidance or detoxification. Thus, carrion 
389 is the site of an intense interkingdom competition between insects and microbial 390 decomposers (Burkepile et al., 2006; Jordan \& Tomberlin, 2017; Young et al., 2015). In 391 this context, burying beetles can cooperate to bury a carcass and limit microbial 392 proliferation (Eggert \& Müller, 2011; Sun et al., 2014; Trumbo, 2017), and blowfly 393 larvae secrete/excrete efficient antimicrobial peptides, which is a property used in larval 394 debridement therapies (Teh et al., 2017). Therefore, larval aggregation may be an 395 adaptive response that locally limits bacterial proliferation and spoiling (see Fig. 7).

\section{Conclusions}

398 The present work demonstrates that calliphorid larvae pre-social behaviour not only 399 results in significant benefits throughout larval development but also may act as a niche-separation mechanism. It has been demonstrated that fly egg-laying strategies can facilitate coexistence in carrion fly communities (Hanski, 1977; Ives, 1989, 1991;

402 Kouki \& Hanski, 1995; Kuusela \& Hanski, 1982; Prinkkilá \& Hanski, 1995; Spindola et 403 al., 2017). Progressing through the stages of decomposition, a carcass becomes 404 attractive to a relatively predictable sequence of insects (Matuszewski et al., 2011; 405 Megnin, 1894). Although highly nutritional, fresh meat is more difficult to ingest and 406 digest than decayed meat (Benbow et al., 2015). By mutualising exodigestion, calliphorid larvae (i.e., pioneer species) possibly make a food source avoided by other necrophagous species more edible. This hypothesis is consistent with the idea that cooperation may enable species to expand their niches (the so-called 'social conquest hypothesis') (Brooks et al., 2017).

\section{Acknowledgments}

414 We thank M. Lihoreau for his helpful comments and the referees who helped us 415 improve the manuscript significantly. 


\section{References}

418

419 Aubernon, C., Boulay, J., Hédouin, V., \& Charabidzé, D. (2016). Thermoregulation in 420 gregarious dipteran larvae: evidence of species-specific temperature selection. 421 Entomologia Experimentalis et Applicata, 160, 101-108.

422 https://doi.org/10.1111/eea.12468

423 Allee, W. C. (1927). Animal Aggregations. The Quarterly Review of Biology, 2, 367424 398. https://doi.org/10.1086/394281

425 Arce, A. N., Smiseth, P. T., \& Rozen, D. E. (2013). Antimicrobial secretions and social 426 immunity in larval burying beetles, Nicrophorus vespilloides. Animal Behaviour, 86, 427 741-745. https://doi.org/10.1016/j.anbehav.2013.07.008

428 Barnard, D. R., \& Geden, C. J. (1993). Influence of Larval Density and Temperature in 429 Poultry Manure on Development of the House Fly (Diptera: Muscidae). Environmental 430 Entomology, 22, 971-977. https://doi.org/10.1093/ee/22.5.971

431 Barnes, K. M., \& Gennard, D. E. (2013). Rearing bacteria and maggots concurrently: a 432 protocol using Lucilia sericata (Diptera: Calliphoridae) as a model species. Applied 433 Entomology and Zoology, 48, 247-253. https://doi.org/10.1007/s13355-013-0181-7

434 Benbow, M. E., Tomberlin, J. K., \& Tarone, A. M. (2015). Carrion Ecology, Evolution, 435 and Their Applications. CRC Press.

436 Bernhardt, V., Schomerus, C., Verhoff, M. A., \& Amendt, J. (2017). Of pigs and men437 comparing the development of Calliphora vicina (Diptera: Calliphoridae) on human and 438 porcine tissue. International Journal of Legal Medicine, 131, 847-853. 439 https://doi.org/10.1007/s00414-016-1487-0 
440 Boulay, J., Deneubourg, J.-L., Hédouin, V., \& Charabidzé, D. (2016). Interspecific

441 shared collective decision-making in two forensically important species. Proceedings of 442 the Royal Society B: Biological Sciences, 283, 20152676. 443 https://doi.org/10.1098/rspb.2015.2676

444 Boulay, J., Devigne, C., Gosset, D., \& Charabidze, D. (2013). Evidence of active 445 aggregation behaviour in Lucilia sericata larvae and possible implication of a 446 conspecific mark. Animal Behaviour, 85, 1191-1197. 447 https://doi.org/10.1016/j.anbehav.2013.03.005

448 Brodie, B. S., Wong, W. H. L., VanLaerhoven, S., \& Gries, G. (2014). Is aggregated 449 oviposition by the blow flies Lucilia sericata and Phormia regina (Diptera: Calliphoridae) 450 really pheromone-mediated? Insect Science, 00, 1-10. https://doi.org/10.1111/1744$451 \quad 7917.12160$

452 Broly, P., Devigne, L., Deneubourg, J.-L., \& Devigne, C. (2014). Effects of group size 453 on aggregation against desiccation in woodlice (Isopoda: Oniscidea). Physiological 454 Entomology, 39, 165-171. https://doi.org/10.1111/phen.12060

455 Brooks, K. C., Maia, R., Duffy, J. E., Hultgren, K. M., \& Rubenstein, D. R. (2017). 456 Ecological generalism facilitates the evolution of sociality in snapping shrimps. Ecology 457 Letters, 20, 1516-1525. https://doi.org/10.1111/ele.12857

458 Bryant, E. H. (1977). Morphometric adaptation of the housefly, Musca domestica L., in 459 the United States. Evolution, 31, 580-596. https://doi.org/10.1111/j.1558$460 \quad 5646.1977 . t b 01046 . x$

461 Burkepile, D. E., Parker, J. D., Woodson, C. B., Mills, H. J., Kubanek, J., Sobecky, P. 462 A., \& Hay, M. E. (2006). Chemically mediated competition between microbes and 
463 animals: microbes as consumers in food webs. Ecology, 87, 2821-2831.

464 https://doi.org/10.1890/0012-9658(2006)87[2821:CMCBMA]2.0.CO;2

465 Chambers, L., Woodrow, S., Brown, A. P., Harris, P. D., Phillips, D., Hall, M., Pritchard, 466 D. I. (2003). Degradation of extracellular matrix components by defined proteinases 467 from the greenbottle larva Lucilia sericata used for the clinical debridement of non468 healing wounds. British Journal of Dermatology, 148, 14-23. 469 https://doi.org/10.1046/j.1365-2133.2003.04935.x

470 Charabidze, D., Bourel, B., \& Gosset, D. (2011). Larval-mass effect: Characterisation 471 of heat emission by necrophageous blowflies (Diptera: Calliphoridae) larval 472 aggregates. Forensic Science International, 211, 61-66. 473 https://doi.org/10.1016/j.forsciint.2011.04.016

474 Charabidze, D., Hedouin, V., \& Gosset, D. (2013). Discontinuous foraging behavior of 475 necrophagous Lucilia sericata (Meigen 1826) (Diptera Calliphoridae) larvae. Journal of 476 Insect Physiology, 59, 325-331. https://doi.org/10.1016/j.jinsphys.2012.12.006

477 Choe, J. C., \& Crespi, B. J. (1997). The Evolution of Social Behaviour in Insects and 478 Arachnids. Cambridge University Press.

479 Cornwallis, C. K., Botero, C. A., Rubenstein, D. R., Downing, P. A., West, S. A., \& 480 Griffin, A. S. (2017). Cooperation facilitates the colonization of harsh environments. 481 Nature Ecology \& Evolution, 1, 0057. https://doi.org/10.1038/s41559-016-0057

482 Costa, J. T. (2006). The other insect societies (Harvard University Press, Vols. 1-1). 483 The Belknap Press of Harvard University Press.

484 Courchamp, F., Berec, L., \& Gascoigne, J. (2008). Allee Effects in Ecology and 485 Conservation. New-York: Oxford University Press. 
486 Davies, L. (1998). Delayed egg production and a possible group effect in the blowfly

487 Calliphora vicina. Medical and Veterinary Entomology, 12, 339-344. 488 https://doi.org/10.1046/j.1365-2915.1998.00124.x

489 Deneubourg, J.-L., Grégoire, J.-C., \& Le Fort, E. (1990). Kinetics of larval gregarious 490 behavior in the bark beetle Dendroctonus micans (Coleoptera: Scolytidae). Journal of 491 Insect Behavior, 3, 169-182. https://doi.org/10.1007/BF01417910

492 Denno, R. F., \& Cothran, W. R. (1975). Niche relationships of a guild of necrophagous 493 flies. Annals of the Entomological Society of America, 68, 741-754. 494 https://doi.org/10.1093/aesa/68.4.741

495 Denno, R. F., \& Cothran, W. R. (1976). Competitive interactions and ecological 496 strategies of Sarcophagid and Calliphorid flies inhabiting rabbit carrion. Annals of the 497 Entomological Society of America, 69, 109-113. https://doi.org/10.1093/aesa/69.1.109

498 DeVault, T. L., Brisbin, J., I. Lehr, \& Rhodes, J., Olin E. (2004). Factors influencing the 499 acquisition of rodent carrion by vertebrate scavengers and decomposers. Canadian 500 Journal of Zoology, 82, 502-509. https://doi.org/10.1139/z04-022

501 Disney, R. H. L. (1986). Morphological and other observations on Chonocephalus 502 (Phoridae) and phylogenetic implications for the Cyclorrhapha (Diptera). Journal of 503 Zoology, 210, 77-87. https://doi.org/10.1111/j.1469-7998.1986.tb03621.x

504 Dos Reis, S. F., Von Zuben, C. J., \& Godoy, W. A. C. (1999). Larval aggregation and 505 competition for food in experimental populations of Chrysomya putoria (Wied.) and 506 Cochliomyia macellaria (F.) (Dipt., Calliphoridae). Journal of Applied Entomology, 123, 507 485-489. https://doi.org/10.1046/j.1439-0418.1999.00397.x 
508 Durisko, Z., Kemp, R., Mubasher, R., \& Dukas, R. (2014). Dynamics of social behavior 509 in fruit fly larvae. PLoS ONE, 9. https://doi.org/10.1371/journal.pone.0095495

510 Eggert, A.-K., \& Müller, J. K. (2011). Timing of oviposition enables dominant female 511 burying beetles to destroy brood-parasitic young. Animal Behaviour, 82, 1227-1233. 512 https://doi.org/10.1016/j.anbehav.2011.09.001

513 El-Moaty, Z. A., \& Kheirallah, A. E. M. (2013). Developmental variation of the blow fly 514 Lucilia sericata (Meigen, 1826) (Diptera: Calliphoridae) by different substrate tissue 515 types. Journal of Asia-Pacific Entomology, 16, 297-300. 516 https://doi.org/10.1016/j.aspen.2013.03.008

517 Erzinçlioglu, Z. (1996). Blowflies (Vol. 23). Slough: The Richmond Publishing Co. Ltd.

518 Feinberg, E. H., \& Pimentel, D. (1966). Evolution of increased "female sex Ratio" in the 519 blowfly (Phaenicia sericata) under laboratory competition with the housefly (Musca 520 domestica). The American Naturalist, 100, 235-244. https://doi.org/10.1086/282417

521 Fenton, A., Wall, R., \& French, N. P. (1999). Oviposition aggregation by the blowfly 522 Lucilia cuprina. Med. Vet. Entomology, 13, 453-456. https://doi.org/10.1046/j.1365$523 \quad 2915.1999 .00184 . x$

524 Flores, M., Crippen, T. L., Longnecker, M., \& Tomberlin, J. K. (2017). Nonconsumptive 525 effects of predatory Chrysomya rufifacies (Diptera: Calliphoridae) larval cues on larval 526 Cochliomyia macellaria (Diptera: Calliphoridae) growth and development. Journal of 527 Medical Entomology, 54, 1167-1174. https://doi.org/10.1093/jme/tjx104

528 Frederickx, C., Dekeirsschieter, J., Verheggen, F. J., \& Haubruge, E. (2013). The 529 community of Hymenoptera parasitizing necrophagous Diptera in an urban biotope. 530 Journal of Insect Science, 13, 1-14. https://doi.org/10.1673/031.013.3201 
531 Frederickx, C., Dekeirsschieter, J., Verheggen, F. J., \& Haubruge, E. (2014). Host-

532 habitat location by the parasitoid, Nasonia vitripennis Walker (Hymenoptera:

533 Pteromalidae). Journal of Forensic Sciences, 59, 242-249.

534 https://doi.org/10.1111/1556-4029.12267

535 Godoy, W. a. C., Von Zuben, C. J., Reis, S. dos, \& Von Zuben, F. J. (1996).

536 Theoretical estimates of consumable food and probability of acquiring food in larvae of

537 Chrysomya putoria (Diptera: Calliphoridae). Memórias Do Instituto Oswaldo Cruz, 538 91(2), 257-264. https://doi.org/10.1590/S0074-02761996000200026

539 Gomes, L., Godoy, W. A. C., \& Zuben, C. J. V. (2006). A review of postfeeding larval 540 dispersal in blowflies: implications for forensic entomology. Naturwissenschaften, 93, 541 207. https://doi.org/10.1007/s00114-006-0082-5

542 Goodbrod, J. R., \& Goff, M. L. (1990). Effects of Larval Population Density on Rates of

543 Development and Interactions between Two Species of Chrysomya (Diptera:

544 Calliphoridae) in Laboratory Culture. Journal of Medical Entomology, 27(3), 338-343.

545 https://doi.org/10.1093/jmedent/27.3.338

546 Grassberger, M., \& Reiter, C. (2001). Effect of temperature on Lucilia sericata (Diptera:

547 Calliphoridae) development with special reference to the isomegalen- and isomorphen-

548 diagram. Forensic Science International, 120, 32-36. https://doi.org/10.1016/S0379-

$549 \quad 0738(01) 00413-3$

550 Grassé, P.-P. (1946). Sociétés animales et effet de groupe. Cellular and Molecular Life

551 Sciences, 2, 77-82-82.

552 Green, P. W. C., Simmonds, M. S. J., \& Blaney, W. M. (2002). Does the size of larval 553 groups influence the effect of metabolic inhibitors on the development of Phormia 
554 regina (Diptera: Calliphoridae) larvae? European Journal of Entomology, 99, 19-22.

555 DOI:10.14411/eje.2002.005

556 Gruner, S. V., Slone, D. H., Capinera, J. L., \& Turco, M. P. (2017). Volume of larvae is

557 the most important single predictor of mass temperatures in the forensically important

558 calliphorid, Chrysomya megacephala (Diptera: Calliphoridae). Journal of Medical

559 Entomology, 54, 30-34. https://doi.org/10.1093/jme/tjw139

560 Guyénot, É. (1907). L'appareil digestif et la digestion de quelques larves de mouches.

561 Bulletin Scientifique Franco-Belge 41: 353-370.

562 Hanski, I. (1977). An interpolation model of assimilation by larvae of the blowfly Lucilia

563 illustris (Calliphoridae) in changing temperatures. Oikos, 28, 187-195.

564 DOI:10.2307/3543970

565 Hanski, I. (1987). Carrion fly community dynamics: patchiness, seasonality and 566 coexistence. Ecological Entomology, 12, 257-266. https://doi.org/10.1111/j.1365-

567 2311.1987.tb01004.x

568 Heaton, V., Moffatt, C., \& Simmons, T. (2014). Quantifying the temperature of maggot

569 masses and its relationship to decomposition. Journal of Forensic Sciences, 59, 676-

570 682. https://doi.org/10.1111/1556-4029.12396

571 Hobson, R. P. (1931). Studies on the nutrition of blow-fly larvae : I. Structure and

572 function of the alimentary tract. Journal of Experimental Biology, 8, 109-123.

573 Hunter, A. F. (2000). Gregariousness and repellent defences in the survival of 574 phytophagous insects. Oikos, 91, 213-224. https://doi.org/10.1034/j.1600$575 \quad 0706.2000 .910202 . x$ 
576 Huntington, T. E., Higley, L. G., \& Baxendale, F. P. (2007). Maggot development during

577 morgue storage and its effect on estimating the post-mortem interval. Journal of

578 Forensic Sciences, 52, 453-458. https://doi.org/10.1111/j.1556-4029.2007.00385.x

579 Ireland, S., \& Turner, B. (2006). The effects of larval crowding and food type on the

580 size and development of the blowfly, Calliphora vomitoria. Forensic Science

581 International, 159, 175-181. https://doi.org/10.1016/j.forsciint.2005.07.018

582 Ives, A. R. (1989). The optimal clutch size when many females oviposit per patch. The

583 American Naturalist, 133, 671-687. https://doi.org/10.1086/284944

584 Ives, A. R. (1991). Aggregation and coexistence in a carrion fly community. Ecological

585 Monographs, 61, 75-94. https://doi.org/10.2307/1943000

586 Janzen, D. H. (1977). Why fruits rot, seeds mold, and meat spoils. The American

587 Naturalist, 111, 691-713. https://doi.org/10.1086/283200

588 Jiang, Y., Lei, C., Niu, C., Fang, Y., Xiao, C., \& Zhang, Z. (2002). Semiochemicals from

589 ovaries of gravid females attract ovipositing female houseflies, Musca domestica.

590 Journal of Insect Physiology, 48, 945-950. https://doi.org/10.1016/S0022-

591 1910(02)00162-2

592 Johnson, A. P., \& Wallman, J. F. (2014). Effect of massing on larval growth rate.

593 Forensic Science International, 141-149.

594 https://doi.org/10.1016/j.forsciint.2014.05.006

595 Jordan, H. R., \& Tomberlin, J. K. (2017). Abiotic and biotic factors regulating inter-

596 kingdom engagement between insects and microbe activity on vertebrate remains.

597 Insects, 8, 54. https://doi.org/10.3390/insects8020054 
598 Kneidel, K. A. (1984). Competition and disturbance in communities of carrion-breeding 599 Diptera. J Anim Ecol, 53, 849-865. DOI: 10.2307/4663

600 Kouki, J., \& Hanski, I. (1995). Population aggregation facilitates coexistence of many 601 competing carrion fly species. Oikos, 72, 223-227. DOI: 10.2307/3546224

602 Kuusela, S., \& Hanski, I. (1982). The structure of carrion fly communities : the size 603 and the type of carrion. Holartic Ecology, 5, 337-348. https://doi.org/10.1111/j.1600604 0587.1982.tb01048.x

605 Magni, P. A., Dhaliwal, S. S., \& Dadour, I. R. (2016). Effect of continuous and cyclic 606 exposure to a cold environment on the development of larvae of Lucilia sericata 607 (Diptera: Calliphoridae) in different sized larval masses. Journal of Medical 608 Entomology, 53, 782-789. https://doi.org/10.1093/jme/tjw036

609 Martinez Sanchez, A., Smith, K. E., Rojo, S., Marcos-Garcia, M. A., \& Wall, R. (2007). 610 Geographic origin affects larval competitive ability in European populations of the 611 blowfly, Lucilia sericata. Entomologia Experimentalis et Applicata (OnlineEarly Articles), 612 122, 93-98. https://doi.org/10.1111/j.1570-7458.2006.00497.x

613 Matuszewski, S., Bajerlein, D., Konwerski, S., \& Szpila, K. (2011). Insect succession 614 and carrion decomposition in selected forests of Central Europe. Part 3: Succession of 615 carrion fauna. Forensic Science International, 207, 150-163. 616 https://doi.org/10.1016/j.forsciint.2010.09.022

617 Megnin, J. P. (1894). La faune des cadavres: application de l'entomologie à la 618 médecine légale. Gauthier-Villars et fils. 
619 Moe, S. J., Stenseth, N. C., \& Smith, R. H. (2002). Density dependence in blowfly

620 populations: experimental evaluation of non-parametric time-series modelling. Oikos, 621 98(3), 523-533. https://doi.org/10.1034/j.1600-0706.2002.980317.x

622 Pérez, C., Segura, N. A., Patarroyo, M. A., \& Bello, F. J. (2016). Evaluating the 623 biological cycle and reproductive and population parameters of Calliphora vicina 624 (Diptera: Calliphoridae) reared on three different diets. Journal of Medical Entomology, 625 53, 1268-1275. https://doi.org/10.1093/jme/tjw114

626 Picard, C. J., \& Wells, J. D. (2010). The population genetic structure of North American 627 Lucilia sericata (Diptera: Calliphoridae), and the utility of genetic assignment methods 628 for reconstruction of postmortem corpse relocation. Forensic Sci. Int., 195, 63-67. 629 https://doi.org/10.1016/j.forsciint.2009.11.012

630 Pöppel, A.-K., Vogel, H., Wiesner, J., \& Vilcinskas, A. (2015). Antimicrobial peptides 631 expressed in medicinal maggots of the blow fly Lucilia sericata show combinatorial 632 activity against bacteria. Antimicrobial Agents and Chemotherapy, 59, 2508-2514. 633 https://doi.org/10.1128/AAC.05180-14

634 Prinkkilá, M.-L., \& Hanski, I. (1995). Complex competitive interactions in four species of 635 Lucilia blowflies. Ecological Entomology, 20, 261-272. https://doi.org/10.1111/j.1365$636 \quad 2311.1995 . t b 00456 . x$

637 Reigada, C., \& Godoy, W. a. C. (2006). Larval density, temperature and biological 638 aspects of Chrysomya megacephala (Diptera: Calliphoridae). Arquivo Brasileiro de 639 Medicina Veterinária e Zootecnia, 58, 562-566. https://doi.org/10.1590/S0102$640 \quad 09352006000400018$

641 Reis, S. F. dos, Von Zuben, C. J., \& Godoy, W. a. C. (1999). Larval aggregation and 642 competition for food in experimental populations of Chrysomya putoria (Wied.) and 
643 Cochliomyia macellaria (F.) (Dipt., Calliphoridae). Journal of Applied Entomology, 123, 644 485-489. https://doi.org/10.1046/j.1439-0418.1999.00397.x

645 Rivers, D. B., Ciarlo, T., Spelman, M., \& Brogan, R. (2010). Changes in development 646 and heat shock protein expression in two species of flies (Sarcophaga bullata [Diptera: 647 Sarcophagidae] and Protophormia terraenovae [Diptera: Calliphoridae]) reared in 648 different sized maggot masses. Journal of Medical Entomology, 47(4), 677-689. 649 https://doi.org/10.1093/jmedent/47.4.677

650 Rivers, D. B., Thompson, C., \& Brogan, R. (2011). Physiological trade-offs of forming 651 maggot masses by necrophagous flies on vertebrate carrion. Bulletin of Entomological 652 Research, 101, 599-611. https://doi.org/10.1017/S0007485311000241

653 Rivers, D. B., Kaikis, A., Bulanowski, D., Wigand, T., \& Brogan, R. (2012). Oviposition 654 restraint and developmental alterations in the ectoparasitic wasp, Nasonia vitripennis, 655 when utilizing puparia resulting from different size maggot masses of Lucilia illustris, 656 Protophormia terraenovae, and Sarcophaga bullata. Journal of Medical Entomology, 657 49, 1124-1136. https://doi.org/10.1603/ME11232

658 Rohlfs, M., \& Hoffmeister, T. S. (2004). Spatial aggregation across ephemeral resource 659 patches in insect communities: an adaptive response to natural enemies? Oecologia, 660 140, 654-661. https://doi.org/10.1007/s00442-004-1629-9

661 Rohlfs, M., Obmann, B., \& Petersen, R. (2005). Competition with filamentous fungi and 662 its implication for a gregarious lifestyle in insects living on ephemeral resources. 663 Ecological Entomology, 30, 556-563. https://doi.org/10.1111/j.0307-6946.2005.00722.x

664 Rueda, L. C., Ortega, L. G., Segura, N. A., Acero, V. M., \& Bello, F. (2010). Lucilia 665 sericata strain from Colombia: experimental colonization, life tables and evaluation of 666 two artificial diets of the blowfy Lucilia sericata (Meigen) (Diptera: Calliphoridae), 
667 Bogotá, Colombia Strain. Biological Research, 43, 197-203.

668 https://doi.org/10.4067/S0716-97602010000200008

669 Saunders, D. S., \& Bee, A. (2013). Effects of larval crowding on size and fecundity of 670 the blow fly, Calliphora vicina (Diptera: Calliphoridae). European Journal of 671 Entomology, 92, 615-622.

672 Schneider, J. M., \& Bilde, T. (2008). Benefits of cooperation with genetic kin in a 673 subsocial spider. Proceedings of the National Academy of Sciences, 105, 10843674 10846. https://doi.org/10.1073/pnas.0804126105

675 Serra, H., Costa, M. I. S., \& Godoy, W. a. C. (2011). Allee effect in exotic and 676 introduced blowflies. Neotropical Entomology, 40, 519-528. 677 http://dx.doi.org/10.1590/S1519-566X2011000500001

678 Simkiss, K., Daniels, S., \& Smith, R. H. (1993). Effect of population density and 679 cadmium toxicity on growth and survival of blowflies. Environment Pollution, 81, 41-45. 680 https://doi.org/10.1016/0269-7491(93)90026-K

681 Slone, D. H., \& Gruner, S. V. (2007). Thermoregulation in larval aggregations of 682 carrion-feeding blow flies (Diptera: Calliphoridae). Journal of Medical Entomology, 44, 683 516-523. https://doi.org/doi: 10.1603/0022-2585

684 Smith, K. E., \& Wall, R. (1997). Asymmetric competition between larvae of the blowflies 685 Calliphora vicina and Lucilia sericata in carrion. Ecological Entomology, 22, 468-474. 686 https://doi.org/10.1046/j.1365-2311.1997.00093.x

687 Smith, K. G. V. (1986). A manual of forensic entomology. London: Trustees of the 688 British Museum (Natural History). 
689 Spindola, A. F., Zheng, L., Tomberlin, J. K., \& Thyssen, P. J. (2017). Attraction and 690 oviposition of Lucilia eximia (diptera: calliphoridae) to resources colonized by the 691 invasive competitor Chrysomya albiceps (Diptera: Calliphoridae). Journal of Medical 692 Entomology, 54, 321-328. https://doi.org/10.1093/jme/tjw170

693 Sun, S.-J., Rubenstein, D. R., Chen, B.-F., Chan, S.-F., Liu, J.-N., Liu, M. Shen, S.-F. 694 (2014). Climate-mediated cooperation promotes niche expansion in burying beetles. 695 ELife, 3, e02440. https://doi.org/10.7554/eLife.02440

696 Tachibana, S.-I., \& Numata, H. (2001). An artificial diet for blow fly larvae, Lucilia 697 sericata (Meigen) (Diptera: Calliphoridae). Applied Entomology and Zoology, 36, 521698 523. https://doi.org/10.1303/aez.2001.521

699 Teh, C. H., Nazni, W. A., Nurulhusna, A. H., Norazah, A., \& Lee, H. L. (2017). 700 Determination of antibacterial activity and minimum inhibitory concentration of larval 701 extract of fly via resazurin-based turbidometric assay. BMC Microbiology, 17. 702 https://doi.org/10.1186/s12866-017-0936-3

703 Terra, W. R., \& Ferreira, C. (1994). Insect digestive enzymes: properties, 704 compartmentalization and function. Comparative Biochemistry and Physiology Part B: 705 Comparative Biochemistry, 109, 1-62. https://doi.org/10.1016/0305-0491

706 Trumbo, S. T. (2017). Feeding upon and preserving a carcass: the function of prehatch 707 parental care in a burying beetle. Animal Behaviour, 130, 241-249. 708 https://doi.org/10.1016/j.anbehav.2017.07.001

709 Tsubaki, Y., \& Shiotsu, Y. (1982). Group feeding as a strategy for exploiting food 710 resources in the burnet moth Pryeria sinica. Oecologia, 55, 12-20. 711 https://doi.org/10.1007/BF00386712 
712 Ullyett, G. C. (1950). Competition for Food and Allied Phenomena in Sheep-Blowfly

713 Populations. Philosophical Transactions of the Royal Society B: Biological Sciences, 714 234(610), 77-174. https://doi.org/10.1098/rstb.1950.0001

715 Voss, S. C., Spafford, H., \& Dadour, I. R. (2009). Hymenopteran parasitoids of forensic 716 importance: host associations, seasonality, and prevalence of parasitoids of carrion 717 flies in Western Australia. Journal of Medical Entomology, 46, 1210-1219. 718 https://doi.org/10.1603/033.046.0532

719 Wall, R. (1993). The reproductive output of the blowfly, Lucilia sericata. J. Ins. 720 Physiology, 9, 743-750. https://doi.org/10.1016/0022-1910(93)90049-W

721 Wertheim, B. (2005). Evolutionary ecology of communication signals that induce 722 aggregative behaviour. Oikos, 109, 117-124. https://doi.org/10.1111/j.0030$723 \quad 1299.2005 .13340 . x$

724 Wilson, M. R., Nigam, Y., Jung, W., Knight, J., \& Pritchard, D. I. (2016). The impacts of 725 larval density and protease inhibition on feeding in medicinal larvae of the greenbottle 726 fly Lucilia sericata. Medical and Veterinary Entomology, 30, 1-7. 727 https://doi.org/10.1111/mve.12138

728 Young, A., Márquez-Grant, N., Stillman, R., Smith, M. J., \& Korstjens, A. H. (2015). An 729 investigation of red fox (Vulpes vulpes) and eurasian badger (Meles meles) 730 scavenging, scattering, and removal of deer remains: forensic implications and 731 applications. Journal of Forensic Sciences, 60, S39-S55. https://doi.org/10.1111/15564029.12554

733 Zvereva, E. L. (1986). Peculiarities of competitive interaction between larvae of the 734 house fly (Musca domestica) and microscopic fungi. Zoologicheskii Zhurnal. 735 http://agris.fao.org/agris-search/search.do?recordID=US201302008662 

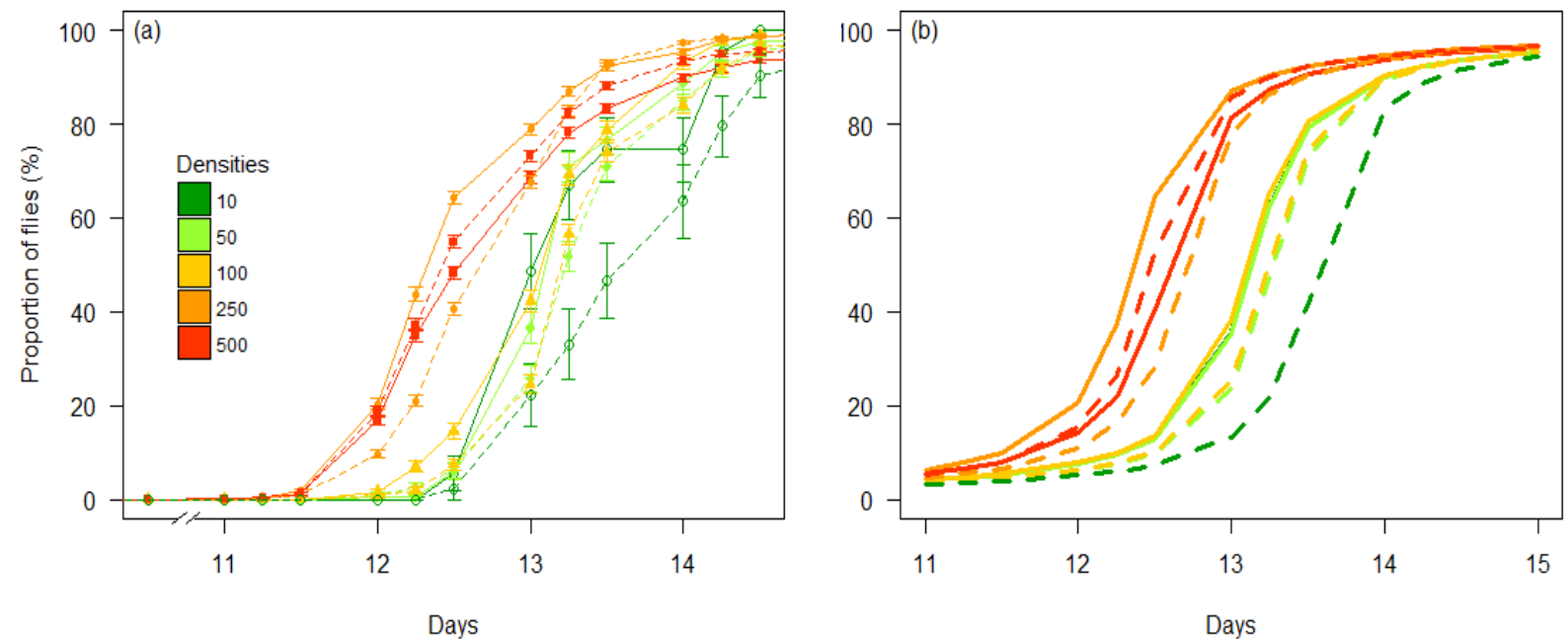

740

741 Figure A1: Kinetics of imago emergence for the control (solid lines) and trypsin (dashed

742 lines) conditions. (a) Percentages \pm SEs of imagos in relation to larval densities. (b)

743 Logistic regressions.

744

745 


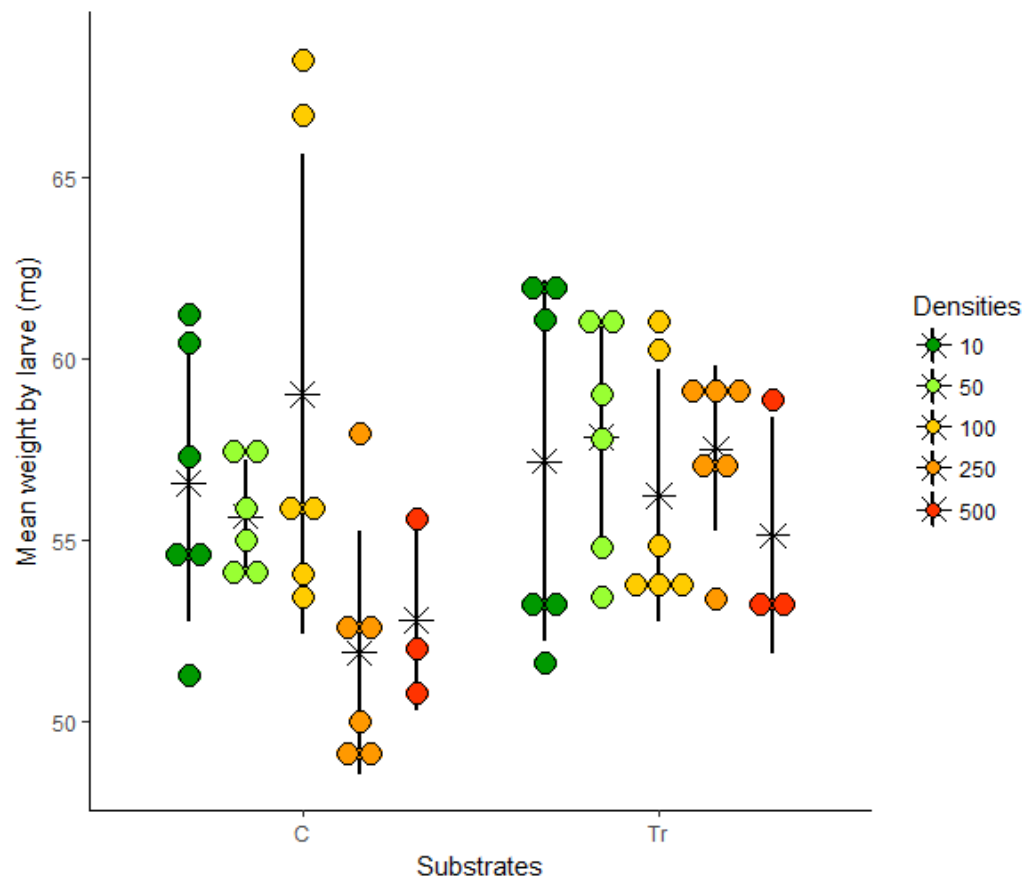

Figure A2: Dot plot of the average weight $( \pm S D)$ of post-feeding larvae per condition. $C$ $751=$ control food; $\mathrm{Tr}=$ trypsin-added food; densities $=$ no. of larvae $/ 50 \mathrm{~g}$ of food. 
754 Figure A3
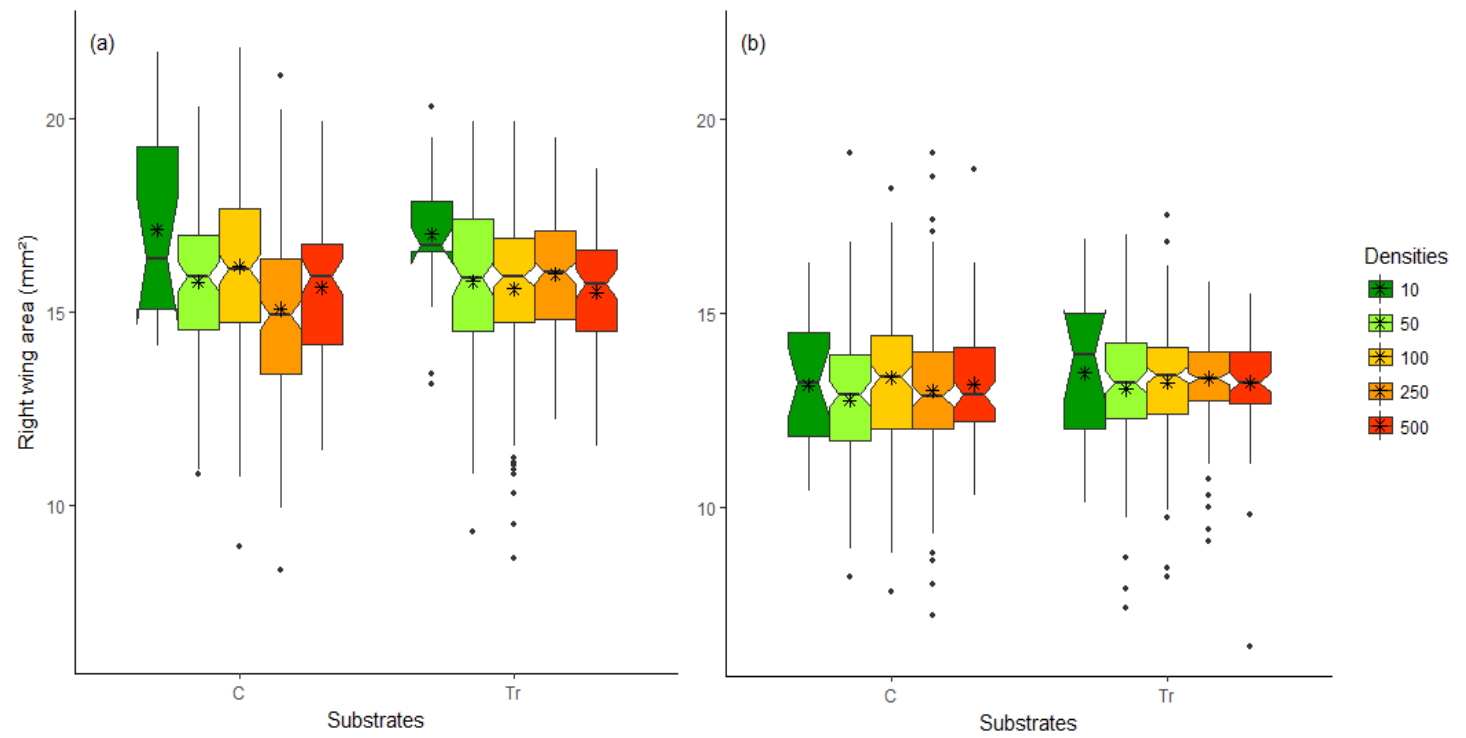

755

756 Figure A3: Box plot of the size of the flies, evaluated by the area of the right wing,

757 according to sex: (a) females; (b) males. ${ }^{*}=$ mean area; $C=$ control food; $\mathrm{Tr}=$ trypsin-

758 added food; densities $=$ no. of larvae $/ 50 \mathrm{~g}$ of food. The box plots show the median and 759 25th and 75th percentiles; the whiskers indicate the values within 1.5 times the 760 interquartile range and the circles are outliers

761

762 


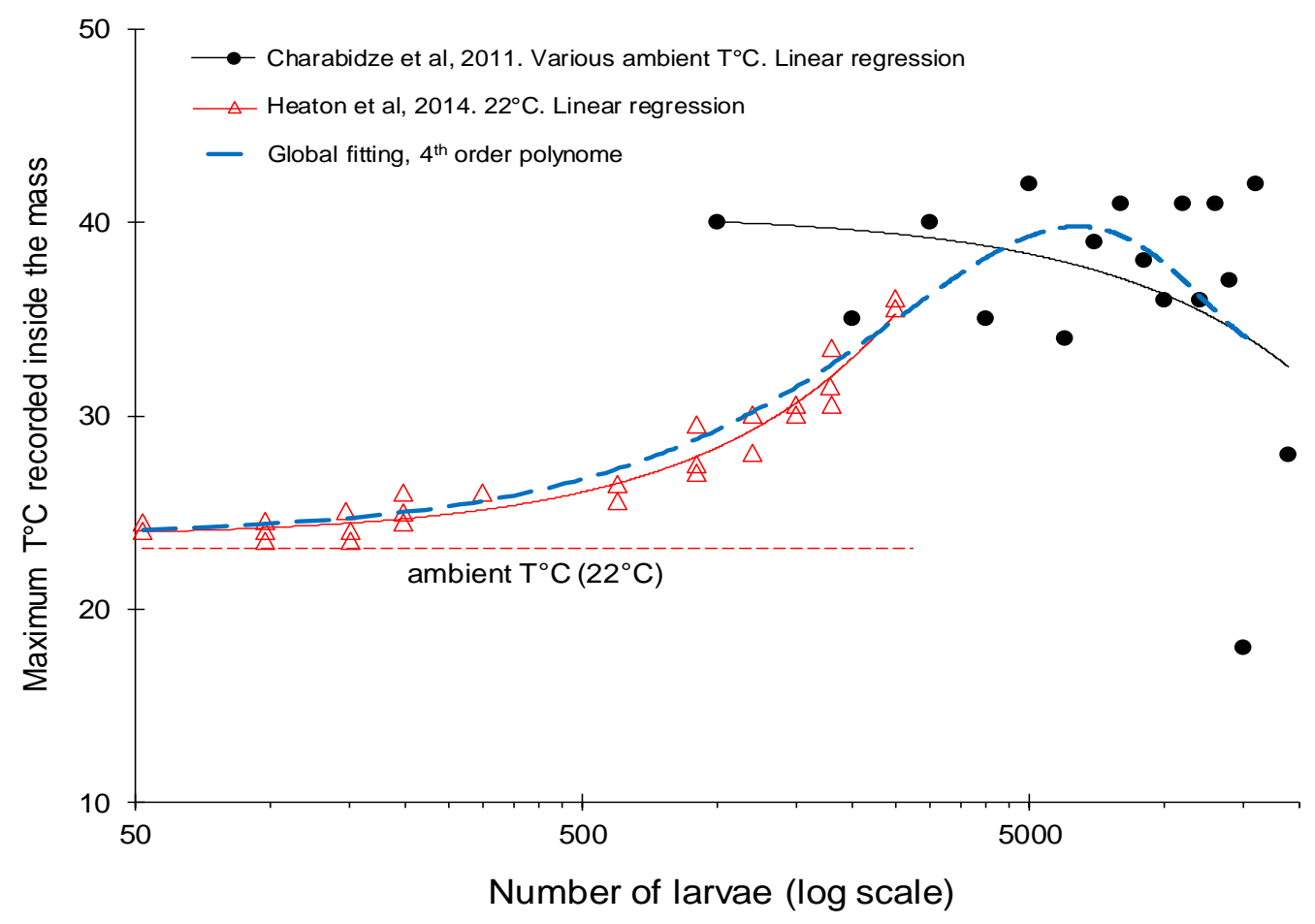

765

766 Figure A4: Peak temperature recorded inside larval aggregates according to 767 Charabidze et al. (2011) and Heaton et al. (2014). Low peak values were observed for 768 small masses (<500 larvae), whereas large masses produced more heat. A ceiling 769 value ca. $40^{\circ} \mathrm{C}$ was observed for the largest masses. 
Table A1: Table of literature review

773

\begin{tabular}{|c|c|c|c|c|c|}
\hline$\underline{\text { Species }}$ & $\begin{array}{l}\text { Larval density } \\
\text { (larvae per } n \text { gram of } \\
\text { substrate) }\end{array}$ & Substrate & Outcomes & Effects & References \\
\hline $\begin{array}{l}\text { Lucilia sericata } \\
\text { Chrysomya albiceps } \\
\text { Chrysomya chloropyga }\end{array}$ & $\begin{array}{l}100 ; 200 ; 500 ; 1000 ; \\
2000 ; 3000 ; 16000 \\
1140 \mathrm{~g}\end{array}$ & Beef & $\begin{array}{l}\text { Development time } \\
\text { Larval weight } \\
\text { Weight and size of pupae } \\
\text { Fecondity of flies } \\
\text { Mortality rate }\end{array}$ & $\begin{array}{l}\text { Increases with increased larval density } \\
\text { Decreases with increased larval density } \\
\text { Decreases with increased larval density } \\
\text { Decreases with increased larval density } \\
\text { Increases with increased larval density }\end{array}$ & $\begin{array}{l}\text { Ullyett et al., } \\
1950\end{array}$ \\
\hline $\begin{array}{l}\text { Chrysomya megacephala } \\
\text { Chrysomya rufifacies }\end{array}$ & $\begin{array}{l}25 ; 50 ; 100 ; 200 ; \\
250 ; 500 \\
/ 25 \mathrm{~g}\end{array}$ & Beef liver & $\begin{array}{l}\text { Development time } \\
\text { Weight and size of pupae and flies } \\
\text { Mortality rate of larvae and pupae }\end{array}$ & $\begin{array}{l}\text { Decreases for the intermediate density from } 100 \text { to } 500 / 25 \mathrm{~g} \\
\text { Decreases with increased larval density } \\
\text { Decreases for the intermediate density from } 100 \text { to } 200 / 25 \mathrm{~g}\end{array}$ & $\begin{array}{l}\text { Goodbrod et al., } \\
1990\end{array}$ \\
\hline Lucilia sericata & $\begin{array}{l}8 \\
/ 4 \mathrm{~g} ; 8 \mathrm{~g} ; 16 \mathrm{~g} ; 32 \mathrm{~g}\end{array}$ & $\begin{array}{l}\text { Agar }+20 \% \text { blood } \\
\text { horse meat }+5 \% \text { yeast }\end{array}$ & $\begin{array}{l}\text { Weight of pupae } \\
\text { Proportion of emergences } \\
\text { Weight of flies }\end{array}$ & $\begin{array}{l}\text { Decreases with increased larval density } \\
\text { Decreases with increased larval density } \\
\text { Decreases with increased larval density }\end{array}$ & $\begin{array}{l}\text { Simkiss et al., } \\
1992\end{array}$ \\
\hline Lucilia sericata & $\begin{array}{l}2 ; 4 ; 8 ; 16 ; 32 ; 64 ; \\
128 ; 256 ; 512\end{array}$ & Beef & $\begin{array}{l}\text { Mortality rate until emergence } \\
\text { Size, fecondity and longevity of flies }\end{array}$ & $\begin{array}{l}\text { Decreases with increased larval density } \\
\text { Decreases with increased larval density }\end{array}$ & $\begin{array}{l}\text { Prinkkilä et al., } \\
1995\end{array}$ \\
\hline Lucilia illustris & & & $\begin{array}{l}\text { Mortality rate until emergence } \\
\text { Size, fecondity and longevity of flies }\end{array}$ & $\begin{array}{l}\text { Increases for the intermediate density } \sim \mathbf{3 2 / 1 9} \text { then strongly decreases } \\
\text { Decreases with increased larval density }\end{array}$ & \\
\hline Lucialia silvarum & & & $\begin{array}{l}\text { Mortality rate until emergence } \\
\text { Size, fecondity and longevity of flies }\end{array}$ & $\begin{array}{l}\text { Decreases with increased larval density } \\
\text { Decreases with increased larval density }\end{array}$ & \\
\hline Lucilia caesar & & & $\begin{array}{l}\text { Mortality rate until emergence } \\
\text { Size, fecondity and longevity of flies }\end{array}$ & $\begin{array}{l}\text { Increases for the intermediate density } \sim \mathbf{1 6 / 1 9} \text { then strongly decreases } \\
\text { Decreases with increased larval density }\end{array}$ & \\
\hline Calliphora vicina & $\begin{array}{l}1 ; 5 ; 10 ; 20 ; 50 ; \\
100 ; 150 ; 200 ; 300 \\
/ 50 \mathrm{~g}\end{array}$ & Beef & $\begin{array}{l}\text { Weight of post-feeding larvae } \\
\text { Development time } \\
\text { Mortality rate } \\
\text { Size of flies }\end{array}$ & $\begin{array}{l}\text { Decreases with increased larval density } \\
\text { Increases with increased larval density } \\
\text { Increases with hincreased larval density } \\
\text { Decreases with increased larval density }\end{array}$ & $\begin{array}{l}\text { Saunders et al., } \\
1995\end{array}$ \\
\hline Chrysomya putoria & $\begin{array}{l}\text { From } 100 \text { to } 2000 \text { (by } \\
100) \\
/ 50 \mathrm{~g}\end{array}$ & $\begin{array}{l}\text { Whole dried milk and } \\
\text { whole dried egg }\end{array}$ & $\begin{array}{l}\text { Weight of pupae } \\
\text { Mortality rate }\end{array}$ & $\begin{array}{l}\text { Decreases with increased larval density } \\
\text { Decreases with increased larval density }\end{array}$ & $\begin{array}{l}\text { Godoy et al. } \\
1996\end{array}$ \\
\hline Lucilia sericata & $\begin{array}{l}10 ; 20 ; 30 ; 50 ; 100 ; \\
150 ; 250 ; 300 ; 500 ; \\
750 ; 1000 ; 1500 \\
/ 15 g\end{array}$ & Lamb liver & $\begin{array}{l}\text { Size of flies } \\
\text { Proportion of emergences }\end{array}$ & $\begin{array}{l}\text { Decreases with increased larval density } \\
\text { Decreases with increased larval density }\end{array}$ & Smith et al., 1997 \\
\hline Calliphora vicina & $\begin{array}{l}10 ; 20 ; 30 ; 50 ; 100 ; \\
150 ; 250 ; 300 ; 500 ; \\
750 ; 1000 ; 1500 \\
/ 15 g\end{array}$ & & $\begin{array}{l}\text { Size of flies } \\
\text { Proportion of emergences }\end{array}$ & $\begin{array}{l}\text { Decreases with increased larval density } \\
\text { Decreases with increased larval density }\end{array}$ & \\
\hline
\end{tabular}

ize of flies

$20 ; 30 ; 50 ; 100$
$: 250 \cdot 300 ; 500$

; $1000 ; 1500$

from 100 to 500/25g

Der 100 to 200/25

sity 16/1g then strongly decreases

Decreases with increased larval density 


\begin{tabular}{|c|c|c|c|c|c|}
\hline $\begin{array}{l}\text { Cochliomyia macelllaria } \\
\text { Chrysomya putoria }\end{array}$ & $\begin{array}{l}200 ; 400 ; 800 ; 1600 \\
/ 50 \mathrm{~g}\end{array}$ & $\begin{array}{l}\text { Whole dried milk and } \\
\text { whole dried egg }\end{array}$ & Mortality rate & Increases with increased larval density & $\begin{array}{l}\text { Dos Reis et al. } \\
1999\end{array}$ \\
\hline Lucilia sericata & $\begin{array}{l}10 ; 50 ; 100 ; 200 ; \\
350 ; 500 \\
1(20 \mathrm{~g} \text { reniewed every } \\
48 \text { hours })\end{array}$ & $\begin{array}{l}\text { Agar }+20 \% \text { blood } \\
\text { horse meat }+5 \% \text { yeast }\end{array}$ & $\begin{array}{l}\text { Mortality rate from first instar to fly } \\
\text { Weights of pupae and flies } \\
\text { Larval development time } \\
\text { Longevity of flies } \\
\text { Fecondity of flies }\end{array}$ & $\begin{array}{l}\text { Decreases slightly with density from } 10 \text { to } 100 \text { then increase, particularly from first } \\
\text { to third instar. The proportion of emergences decrease with the density. } \\
\text { Decreases with increased larval density } \\
\text { Increases with increased larval density } \\
\text { Decreases with increased lavral density } \\
\text { Decreases with increased larval density }\end{array}$ & Moe et al., 2002 \\
\hline Chrysomya megacephala & $\begin{array}{l}200 ; 1000 \\
/ 509\end{array}$ & Beef & $\begin{array}{l}\text { Mortality rate } \\
\text { Fecondity of flies } \\
\text { Size of lfies }\end{array}$ & $\begin{array}{l}\text { No significant difference } \\
\text { Decreases with increased larval density } \\
\text { Decreases with increased larval density }\end{array}$ & $\begin{array}{l}\text { Reigada et al., } \\
2004\end{array}$ \\
\hline Calliphora vomitoria & $\begin{array}{l}1 ; 5 ; 10 ; 20 ; 50 ; 75 ; \\
100 \\
1109\end{array}$ & Prok liver, brain or meat & $\begin{array}{l}\text { Development time from first instar to emergence } \\
\text { Mortality rate } \\
\text { Size of flies }\end{array}$ & $\begin{array}{l}\text { Decreases with increased larval density } \\
\text { Increases with increased larval density } \\
\text { Decreases with increased larval density }\end{array}$ & $\begin{array}{l}\text { Ireland et al., } \\
2005\end{array}$ \\
\hline Lucilia sericata & $\begin{array}{l}20-30 ; 50 ; 150 ; 300 ; \\
650-750 \\
/ 15 g\end{array}$ & Pork liver & $\begin{array}{l}\text { Mortality rate } \\
\text { Size of flies } \\
\text { Development time until emergence }\end{array}$ & $\begin{array}{l}\text { Increases with increased larval density } \\
\text { Decreases with hincreased larval density } \\
\text { No significicant difference }\end{array}$ & $\begin{array}{l}\text { Martinez-Sànchez } \\
\text { et al., } 2007\end{array}$ \\
\hline Protophormia terraenovae & $\begin{array}{l}25 ; 50 ; 100 ; 200 ; \\
50 ; 1000 ; 2000 \\
1150 \mathrm{~g}\end{array}$ & Beef liver & $\begin{array}{l}\text { Development time from larvae to pupariation } \\
\text { Time for emergence } \\
\text { Weight of pupae } \\
\text { Proportion of emergence }\end{array}$ & $\begin{array}{l}\text { Decreases with increased larval density } \\
\text { No significant difference } \\
\text { Decreases with increased larval density } \\
\text { Decreases with increased larval density }\end{array}$ & $\begin{array}{l}\text { Rivers et al. } \\
2010\end{array}$ \\
\hline Lucilia eximia & $\begin{array}{l}100 ; 200 ; 400 ; 600 ; \\
800 \\
/ 50 g\end{array}$ & $\begin{array}{l}\text { Whole dried milk and } \\
\text { whole dried egg }\end{array}$ & $\begin{array}{l}\text { Mortality rate } \\
\text { Fécondity of flies }\end{array}$ & $\begin{array}{l}\text { Increases with increased larval density } \\
\text { Decreases with increased larval density }\end{array}$ & Serra et al., 2011 \\
\hline Chrysomya albiceps & $\begin{array}{l}100 ; 200 ; 400 ; 600 ; \\
800 ; 1000 \\
150 g\end{array}$ & & & & \\
\hline Cochliomyia macelllaria & $\begin{array}{l}\text { from } 200 \text { to } 2000 \text { by } \\
200 \\
/ 50 \mathrm{~g}\end{array}$ & & & & \\
\hline \multicolumn{6}{|l|}{ Chrysomya megacephala } \\
\hline \multicolumn{6}{|l|}{ Chrysomya albiceps } \\
\hline Chrysomya rufifacies & $\begin{array}{l}\text { 10mg; } 50 \mathrm{mg} 100 \mathrm{mg} \text { of } \\
\text { first instar larvae } \\
/ 150 \mathrm{~g}\end{array}$ & Kangaroo meat & $\begin{array}{l}\text { Development time } \\
\text { Weight and size of post-feeding larvae }\end{array}$ & $\begin{array}{l}\text { Decreases with increased larval density } \\
\text { Decreases with increased larval density }\end{array}$ & $\begin{array}{l}\text { Johnson et al., } \\
2014\end{array}$ \\
\hline Calliphora vicina & & & $\begin{array}{l}\text { Development time } \\
\text { Weight and size of post-feeding larvae }\end{array}$ & $\begin{array}{l}\text { No significant difference } \\
\text { Decreases with increased larval density }\end{array}$ & \\
\hline Lucilia sericata & $\begin{array}{l}0 ; 2,5 ; 5 ; 7,5 ; 10 ; \\
12,5 ; 15 \text { (Biobag) } \\
/ 20 \mathrm{~g}\end{array}$ & Pork liver & $\begin{array}{l}\text { Mass of tissues digested after } 48 \mathrm{~h} \\
\text { Average mass by larvae after } 48 \mathrm{~h} \\
\text { Larval mortality rate after } 48 \text { hours }\end{array}$ & $\begin{array}{l}\text { Increases until 7,5 } \\
\text { Decreases from } 5 \\
\text { No significant difference }\end{array}$ & $\begin{array}{l}\text { Wilson et al., } \\
2016\end{array}$ \\
\hline
\end{tabular}

